\title{
Impact of intracellular ion channels on cancer development and progression
}

\author{
Roberta Peruzzo $^{1} \cdot$ Lucia Biasutto $^{2,3} \cdot$ Ildikò Szabò $^{1,2} \cdot$ Luigi Leanza $^{1}$
}

Received: 15 January 2016 / Revised: 13 May 2016 / Accepted: 17 May 2016 / Published online: 11 June 2016

(C) The Author(s) 2016. This article is published with open access at Springerlink.com

\begin{abstract}
Cancer research is nowadays focused on the identification of possible new targets in order to try to develop new drugs for curing untreatable tumors. Ion channels have emerged as "oncogenic" proteins, since they have an aberrant expression in cancers compared to normal tissues and contribute to several hallmarks of cancer, such as metabolic re-programming, limitless proliferative potential, apoptosis-resistance, stimulation of neo-angiogenesis as well as cell migration and invasiveness. In recent years, not only the plasma membrane but also intracellular channels and transporters have arisen as oncological targets and were proposed to be associated with tumorigenesis. Therefore, the research is currently focusing on understanding the possible role of intracellular ion channels in cancer development and progression on one hand and, on the other, on developing new possible drugs able to modulate the expression and/or activity of these channels. In a few cases, the efficacy of channel-targeting drugs in reducing tumors has already been demonstrated in vivo in preclinical mouse models.
\end{abstract}

Keywords Ion channels · Cancer · Mitochondria $\cdot$ Cancer cell metabolism · Organelles

Special Issue: Ion Channels, Transporters and Cancer.

Luigi Leanza

luigi.leanza@unipd.it

1 Department of Biology, University of Padua, Padua, Italy

2 CNR Institute of Neuroscience, Padua, Italy

3 Department of Biomedical Sciences, University of Padua, Padua, Italy

\section{Introduction}

In the last decades, cancer research has been focused on identifying novel targets for therapy, especially on trying to develop new strategies to fight untreatable tumors. Almost 20 years ago, ion channels were proposed as potential targets: they are often aberrantly expressed in cancer tissues compared to healthy ones, and, importantly, there are many pharmacological tools already available to manipulate them. Ion channels have been demonstrated to contribute to the acquirement of several hallmarks of cancer cells (Hanahan and Weinberg 2011): metabolic re-programming (e.g., Andersen et al. 2014; Leanza et al. 2013a, 2014b), limitless proliferative potential (Urrego et al. 2014; Pardo and Stühmer 2014), apoptosis resistance (Wang 2004; Hoffmann and Lambert 2014), stimulation of neo-angiogenesis (Munaron 2015) as well as cell migration and invasiveness (Litan and Langhans 2015; Djamgoz and Onkal 2013). In recent years, not only plasma membrane channels but also intracellular ones have been related to the control of some typical features in cancer cells (Leanza et al. 2013a). Inside the cell, ion channels are expressed in several organelles (Xu et al. 2015): mitochondria, endoplasmic reticulum, nucleus, lysosome, Golgi apparatus, peroxisomes and endosomes. Most of the identified "oncogenic" intracellular channels are located in the outer or inner mitochondrial membrane (OMM and IMM), since this organelle is a key point of control of important hallmarks of cancer, such as ATP-linked metabolism and apoptotic cell death. Another relevant intracellular location is the endoplasmic reticulum (ER): ion channels and transporters of the ER modulate the cytosolic $\mathrm{Ca}^{2+}$ concentration by controlling the uptake and release of calcium from this intracellular store and thus impact several cellular pathways implicated in the determination of cell fate as well in cell metabolism. Figure 1 
summarizes the intracellular channels that have been linked to tumorigenesis or have been identified as possible targets.

The relevance of studying oncogenic channels is underlined by recent studies demonstrating that their pharmacological modulation can reduce tumor growth even in vivo in preclinical models of brain, lung, stomach, colon, blood, cervix, bladder, skin, prostate, breast, esophagus and oral cavity cancers (Leanza et al. 2015a).

In this review, we discuss intracellular channels whose altered expression has been related to cancer development or progression. Furthermore, we mention cases where pharmacological modulation of these channels points toward a possibility of exploiting them for treatment.

\section{Mitochondrial channels}

\section{Voltage-dependent anion channel (VDAC)}

The identification of voltage-dependent anion channels (VDACs) succeeded using electrophysiology and electron microscopy, since it was demonstrated that the outer mitochondrial membrane (OMM) leak was due to unique anion-selective channels, which transport cations, such as $\mathrm{Ca}^{2+}$, as well as many charged and non-charged metabolites, with selectivity for anions over cations being modified by membrane voltage (Colombini and Mannella 2012).

VDAC mediates metabolic cross-talk between the mitochondria and the rest of the cell (Shoshan-Barmatz et al. 2010; Shoshan-Barmatz and Mizrachi 2012; Reddy 2013), is a key player in the regulation of mitochondriamediated apoptosis and is implicated in cancer and neurodegenerative disorders (Shoshan-Barmatz et al. 2010; Shoshan-Barmatz and Golan 2012; Shoshan-Barmatz and Mizrachi 2012; Reddy 2013). In mammals, three versions of VDAC have been identified, VDAC1, VDAC2 and VDAC3 (Blachly-Dyson and Forte 2001), which have similar molecular weights (30-35 kDa), share approximately $70 \%$ identity and show structural and functional homology. The three isoforms are nearly ubiquitous in all tissue types, with VDAC2 and VDAC3 expression being lower than VDAC1 (Messina et al. 2012). Recombinant VDAC1 and VDAC2 form channels upon reconstitution into a lipid bilayer (BLM) (Xu et al. 1999). Recently, also hVDAC3 was shown to give rise to channel activity in BLM displaying however a very small conductance $(100 \mathrm{pS})$ in

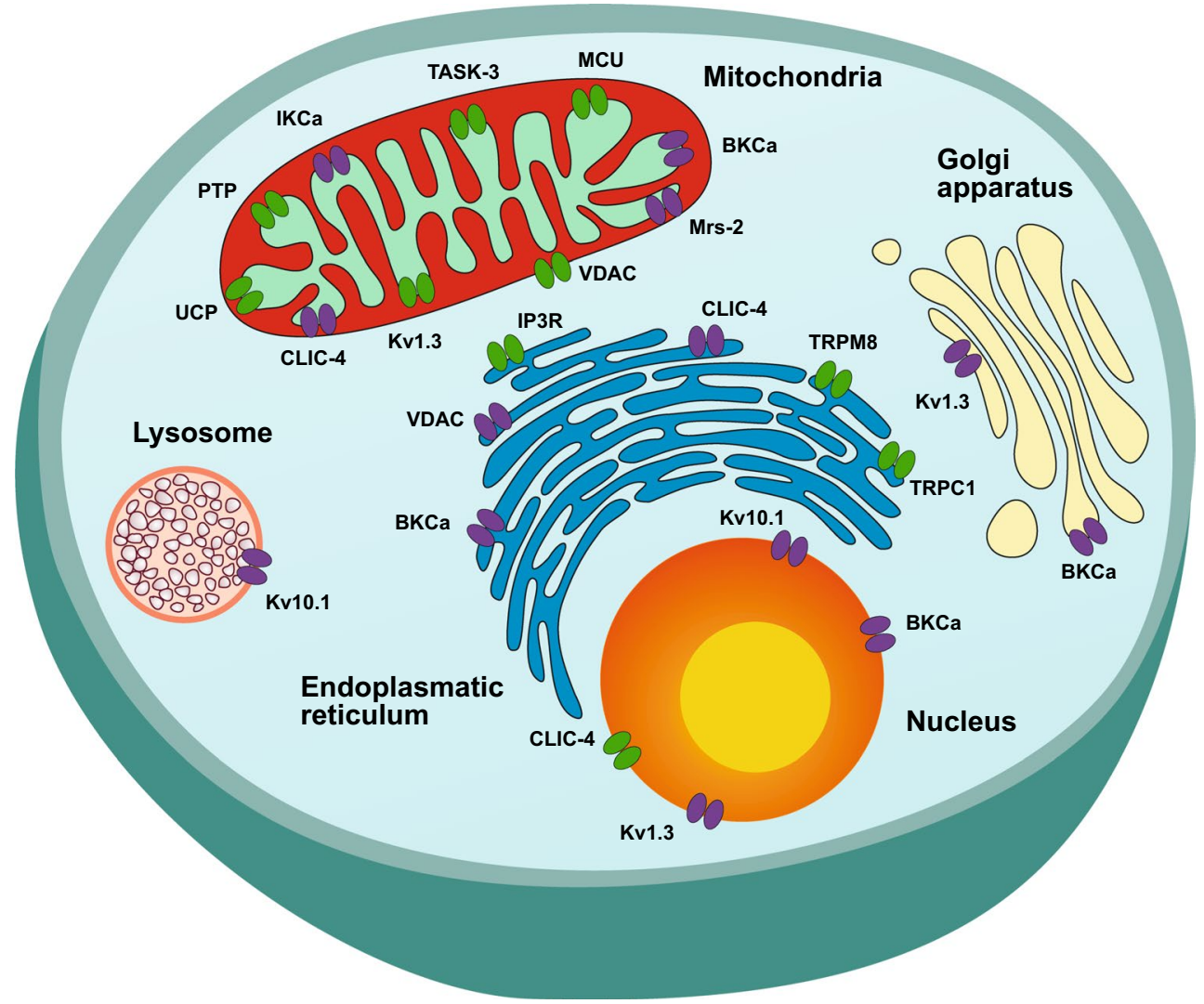

Fig. 1 Intracellular ion channels are expressed in several subcellular compartments, such as the nucleus, endoplasmic reticulum, Golgi apparatus, lysosome and mitochondria. Ion channels, whose role in cancer development and/or progression has been demonstrated, are stained in green 
contrast to VDAC1 ( $4 \mathrm{nS}$ in $1 \mathrm{M} \mathrm{KCl}$ ) (Checchetto et al. 2014). VDAC3 has recently been proposed to act as a redox sensor in the cells, given that its function depends on the redox state of critical cysteine residues that face the intermembrane space (Reina et al. 2016). Interestingly, there are many cases where VDACs have been mutated in various cancer tissues, although the relevance of these mutations in the context of tumor progression is still unclear (Naghdi and Hajnóczky 2016).

Besides its presence in the OMM, VDAC1 has also been localized by immunofluorescence, flow cytometry and EM immunogold labeling in other cell compartments, such as the plasmamembrane (De Pinto et al. 2010), sarcoplasmic reticulum of skeletal muscles (Shoshan-Barmatz et al. 1996), endoplasmic reticulum (ER) of rat cerebellum (Shoshan-Barmatz et al. 2004) and caveolae and caveolae-like domains. However, its function in compartments other than the mitochondria is less clear.

VDAC1 is overexpressed in many cancer types (Shoshan-Barmatz et al. 2015). Thus, VDAC1 is an excellent target for anti-cancer therapy since thanks to its observed low genetic variability between patients, the chances that tumors will develop resistance to VDAC1-based drugs by acquiring mutations in VDAC1 are low. The role of VDAC1 in cellular metabolism is crucial, since it serves as the main interface between mitochondrial and cellular metabolisms by allowing a two-way traffic: it mediates the entry of metabolites including pyruvate, malate, succinate, ADP and NADH into mitochondria and the exit of newly formed molecules, such as hemes and ATP (Shoshan-Barmatz et al. 2015). Furthermore, VDAC1 is involved in the regulation of apoptosis, thanks to its role in the release of apoptosis-inducing proteins from the mitochondria to the cytosol (Shoshan-Barmatz et al. 2015).

Importantly, downregulation of VDAC1 expression resulted in a reduced metabolite exchange between mitochondria and the cytosol, inhibited cell growth (AbuHamad et al. 2006) and prevented cell death induced by cisplatin (Tajeddine et al. 2008) and endostatin (Yuan et al. 2008). On the contrary, overexpression of VDAC1 was found to induce apoptotic cell death following apoptotic stimuli (Godbole et al. 2003; Zaid et al. 2005; Ghosh et al. 2007; Lu et al. 2007; Abu-Hamad et al. 2008).

The metabolic advantage given by VDAC1 overexpression to cancer cells is due to the fact that it presents binding sites for overexpressed Hexokinase, allowing direct transport of mitochondrial ATP for glucose phosphorylation, thus increasing the glycolytic rate, a characteristic of cancer cells (i.e., the Warburg effect). In addition, VDAC1 also binds Bcl-2 and Bcl-xL, anti-apoptotic proteins expressed in many cancer cells, and impacts their cell-saving function (Shoshan-Barmatz et al. 2015). Bcl-xL was shown to interact with VDAC1 to inhibit apoptosis promoted by mitochondrial $\mathrm{Ca}^{2+}$ uptake (Roy et al. 2009; Monaco et al. 2015). Similary, binding of Bcl-2 to VDAC1 inhibits cytochrome c release and apoptosis (Abu-Hamad et al. 2009). In contrast, other studies showed that VDAC1 interacts with Bax to exert a pro-apoptotic effect (Shimizu et al. 2000; Shi et al. 2003).

Several studies have shown differences in the expression of VDAC between cancer cell lines and tissues with respect to the normal counterparts: high VDAC1 levels were observed in hepatoma, sarcomatous alterations (Yoo et al. 2009), non-small-cell lung cancer (NSCLC) cells (Brahimi-Horn et al. 2012), gastric cancer cells (Bai et al. 2011) and different cancer types, such as thyroid, lung, cervix, ovary, pancreas, melanoma and glioblastoma cancers. A several-fold increase in VDAC1 expression was shown also in peripheral blood mononuclear cells from chronic lymphocytic leukemia (CLL) patients (Shoshan-Barmatz et al. 2015). In addition, in melanoma and prostate cancer cell lines, a positive correlation between levels of VDAC1 expression and the release of cytochrome c by G3139 was demonstrated (Lai et al. 2006). VDAC1 expression was also correlated with tumor progression and sensitivity to chemotherapy (Simamura et al. 2008; Pernemalm et al. 2013), whereas gene expression or proteomic analysis of NSCLC or primary lung adenocarcinoma patients revealed high VDAC1 expression levels as a predictor of poor outcome (Grills et al. 2011; Pernemalm et al. 2013). Thus, determination of VDAC1 expression levels can be useful as a molecular biomarker to predict cancer development and treatment efficacy.

Several drugs have been shown to interact with VDAC1 and affect its ability to bind hexokinase and Bcl-2 family member proteins (for a recent review, see, e.g., Szabò and Zoratti 2014): erastin (Yagoda et al. 2007), oblimersen (G3139) (Advani et al. 2011; Pro et al. 2008; Rom et al. 2009; Lai et al. 2006), avicins (Haridas et al. 2005; Gaikwad et al. 2005), cisplatin (Yang et al. 2006; Castagna et al. 2004), endostatin (Yuan et al. 2008) and methyl jasmonate (MJ) (Raviv et al. 2013).

Unfortunately, most of these drugs have pleiotropic effects so that their specificity for VDAC1 is not guaranteed. Indeed, a more specific approach involving specific screening would be required to discover possible novel VDAC1 interactors. In this respect, the design of cell-penetrating VDAC1-based peptides (Shoshan-Barmatz et al. 2015) that impair the interaction between the channel and metabolic regulators and thus impact energy homeostasis and minimize the self-defense mechanisms of cancer cells represents a novel and innovative strategy.

Besides VDAC1, VDAC2 also displays cancer-related features. For example, it is also highly expressed in cancer lines and tissues, and the main target of erastin (see above) is VDAC2. VDAC2 seems to have unique, non-redundant 
fundamental functions in development and survival, possibly by impacting the mitochondrial import and OMMpermeabilizing function of Bak pro-apoptotic Bcl-2 family proteins, although VDAC2's role as a promoter or inhibitor of death is still debated (Naghdi and Hajnóczky 2016).

\section{Permeability transition pore (PTP)}

The permeability transition pore (PTP) is a voltage- and $\mathrm{Ca}^{2+}$-dependent high-conductance channel $(1.3 \mathrm{nS}$ in $150 \mathrm{mM} \mathrm{KCl}$ ) (Zoratti and Szabò 1995) that is able to dramatically increase in the permeability of the IMM to solutes with molecular mass up to $1500 \mathrm{Da}$ (Bernardi et al. 2006). Indeed, a series of events occurring following PTP opening, including mitochondrial depolarization, generation of reactive oxygen species (ROS), release of mitochondrial $\mathrm{Ca}^{2+}$ and swelling of mitochondria leading to breaches in the OMM that induce the release of intermembrane proteins, promotes this channel as a promising oncological target (Rasola and Bernardi 2014). Clearly, long-lasting opening of PTP compromises mitochondrial function and leads to various forms of cell death (apoptosis, necrosis and necroptosis). The key characteristics of PTP are: inhibition by $\mathrm{CsA}$, adenine nucleotides, $\mathrm{Mg}^{2+}$, acidic $\mathrm{pH}$ and reducing agents, induction by $\mathrm{Ca}^{2+}$ and voltage sensitivity (Bernardi et al. 1992; Kinnally et al. 1989; Petronilli et al. 1989, 1991, 1992).

Recently, it has been proposed that the PTP is formed by dimers of the $\mathrm{F}_{\mathrm{O}} \mathrm{F}_{1}$ ATP synthase (Giorgio et al. 2013) or by the c-ring of the ATP-producing machinery (Alavian et al. 2014). It has recently been demonstrated that purified ATP synthase from various organisms forms a channel that is similar to the PTP channel and that ablation of e and $g$ ATP synthase subunits of the yeast ATP synthase, which seems to be required for dimer formation, leads to a marked resistance to PTP opening (Carraro et al. 2014). Nevertheless, the molecular identity of the PTP is still debated. A recent work identified mitochondrial spastic paraplegia 7 (SPG7), a nuclear-encoded mitochondrial metalloprotease (m-AAA) that interacts with cyclophilin D and VDAC1 at the IMM and OMM contact site and with a paraplegin-like protein AFG3L2 in the IMM, as an essential component of PTP (Shanmughapriya et al. 2015, but see also Bernardi and Forte 2015). Interestingly, downregulation of SPG7 expression, however only a minor one, can be observed in different cancer tissues (see Table 1): we performed an in silico analysis based on the Oncomine ${ }^{\circledR}$ Research Edition, a web application that integrates and unifies high-throughput cancer-profiling data across a large volume of cancer types, subtypes and experiments so that target expression can be assessed online, to compare expression of a given protein in several cancers compared to normal tissues.

As mentioned above, PTP opening induces apoptosis by massive $\mathrm{Ca}^{2+}$ release into the cytosol and by impairment of mitochondrial function. The resistance to cell death induction under stress conditions is a key feature of cell progression to malignancy (Hanahan and Weinberg 2000, 2011), and, indeed, some chemotherapeutics are designed to selectively reactivate apoptosis in cancer cells. PTP inhibition is an important adaptation mechanism that acts as a tumorenhancer event in the model of hepatocarcinogenesis triggered by 2-acetylaminofluorene in rats (Klohn et al. 2003).

Therefore, comprehension of the PTP structure and regulation in cancer progression as well as identification of selective PTP activators is very important to develop anti-neoplastic strategies. However, it has to be mentioned, that the possibility of a selective action on ATP synthase only in cancer cells seems unlikely. Nevertheless, several compounds that open the PTP are under scrutiny as potential chemotherapeutics. Many of them, such as the plantderived alkaloid berberine (Zhang et al. 2014), the plant hormone methyl jasmonate (Raviv et al. 2013), the monocyclic sesquiterpene alcohol-bisabolol (Cavalieri et al. 2009), the naphtho-quinone shikonin (Han et al. 2007), the triterpenoid betulinic acid (Lena et al. 2009), the constituent of turmeric powder curcumin (Qiu et al. 2014), the polyphenolic compounds resveratrol (Ma et al. 2007) and honokiol (Li et al. 2007b), are natural compounds that have been tested on tumor cell lines and in vivo in preclinical animal models, and some of them are currently undergoing clinical or pre-clinical trials (Leanza et al. 2014b; Suh et al. 2013).

Most of the above-mentioned agents display pro-apoptoptic and anti-neoplastic effects because they induce PTP opening due to increased oxidative stress. Cancer cells exhibit elevated ROS levels, which are produced by both by
Table 1 Oncomine analysis of $S P G 7$ gene in several human cancer tissues. Here are reported only tumors in which gene expression was changed at least twice compare to normal tissues

\begin{tabular}{lllll}
\hline Gene & Tissue & Tumor & C vs. N & References \\
\hline SPG7 & Sarcoma & Pleomorphic liposarcoma & -2.502 & Detwiller et al. (2005) \\
& Ovary & Ovarian serous surface papillary carcinoma & -2.089 & Welsh et al. (2001) \\
& Lung & Small cell lung carcinoma & -4.506 & Bhattacharjee et al. (2001) \\
& Kidney & Renal Wilms' tumor & -2.232 & Yusenko et al. (2009) \\
& Renal oncocytoma & -2.735 & Yusenko et al. (2009) \\
& Breast & Invasive breast carcinoma & -2.278 & Finak et al. (2008) \\
\hline
\end{tabular}


changes in their metabolism as well as exposure to inappropriate oxygen concentrations (Grek and Tew 2010). This increased level of ROS must be kept under tight control by enhancing antioxidant defenses (De Nicola et al. 2011) in order to avoid the ROS' damaging effects on several cellular structures, especially in the early tumorigenic phases (Cairns et al. 2011). Under these conditions, the cellular fate is the result of a balance between ROS generation and scavenging, and cancer cells are more vulnerable than normal ones to further oxidative insults. Thus, drugs that act on oxidative damage may represent a strategy for selectively targeting cancer cells (Gorrini et al. 2013). Since PTP induction causes cell death by oxidative stress (Rasola and Bernardi 2011), several pro-oxidant agents that are able to open PTP lead on one hand to an increase in intracellular $\mathrm{Ca}^{2+}$ release (due to loss of impermeability) and on the other hand to inhibition of ATP-dependent $\mathrm{Ca}^{2+}$ extrusion from the plasmamembrane (due to membrane potential loss and decreased ATP synthesis) (Camello-Almaraz et al. 2006). Indeed, mitochondria are the most important sites for ROS production. ROS produced by the respiratory chain complexes can be exported into the cytosol where they can activate the ER-located IP3 and ryanodine receptors, which can release $\mathrm{Ca}^{2+}$ from this intracellular store. In turn, this $\mathrm{Ca}^{2+}$ will be (partially) buffered by the MCU. Intra-mitochondrial calcium activates synthesis of reduced substrates (NADH) by metabolic pathways and accelerates the electron transport chain, increasing ROS production, which in turn facilitates $\mathrm{Ca}^{2+}$ release by sensitization of IP3R and RyR (Camello-Almaraz et al. 2006). Therefore, strategies to elicit PTP opening can be envisioned as promising anti-neoplastic approaches, even if the possibility of side effects, e.g., on the nervous system or cardiac tissues, must be carefully considered (Leanza et al. 2014b). Conversely, CsA inhibition of the PTP promotes skin cancer in transplant patients, highlighting the key role of PTP inhibition in tumor development (Norman et al. 2010).

Interestingly, overexpression of a serine protease inhibitor of the serpin family, called SERPINB3 (SB3), causes an antioxidant defense mechanism in cancer cells: SB3 locates inside the mitochondria where it inhibits respiratory complex I, thus blocking ROS generation following chemotherapeutic treatment and protecting cells from PTP opening (Ciscato et al. 2014). Further links among PTP induction, ROS generation and respiratory complexes came from studies on the serine/threonine kinase GSK-3, a kinase involved in a variety of biological processes. GSK-3 is constitutively active and exerts an inhibitory effect on its targets and can be itself regulated by serine or tyrosine phosphorylation (Jope and Johnson 2004; Jope et al. 2007). A fraction of the enzyme, called mGSK-3, is located inside in the mitochondria (Chiara and Rasola 2013), where it down-modulates both the Krebs cycle (Hoshi et al. 1996) and oxidative phosphorylation (King et al. 2008), thus constituting an integration point for targets acting on PTP (Juhaszova et al. 2009; Miura and Miki 2009).

In addition, several lines of evidence connect hexokinase II to the PTP, and, for example, it has been shown that detachment of hexokinase II from mitochondria by a selective peptide induces PTP opening triggered apoptosis in several tumor cell models independently of VDAC (Chiara et al. 2008).

In general, mitochondrial hexokinase II is a good target in anti-cancer strategies, since it is required for tumor initiation and maintenance in mouse models of K-Ras-driven lung cancer, as its ablation in conditional knockout mice inhibits tumor growth without side effects (Patra et al. 2013). However, further studies are needed to better understand whether all compounds that target mitochondrial hexokinase II can lead to PTP opening.

Recently, it has been proposed that PTP regulation of tumor cells can be regulated also by molecular chaperones. In particular, the oncogenic TRAP1 was shown to interact with succinate dehydrogenase (SDH), inhibiting succinate oxidation and inducing a pseudohypoxic response (i.e., HIF1 activation in normoxic conditions) (Sciacovelli et al. 2013), but also by shielding tumor cells from ROS-induced PTP opening and death. A decreased TRAP1 expression level was observed in some high-grade tumors. Furthermore, TRAP1 and also the mitochondrial pools of Hsp90 and Hsp60 were reported to interact with CyPD and prevent its ability to induce the pore opening in tumor cell models (Kang et al. 2007; Ghosh et al. 2010). Further work is required to dissect the mode of action of each of these molecular chaperones on the PTP. In summary, PTP is certainly one of the most promising intracellular channels as an oncological target along with VDACs.

\section{The mitochondrial calcium uniporter (MCU)}

Mitochondria act as intracellular conductors of intracellular $\mathrm{Ca}^{2+}$ regulation, shaping, remodeling, relaying and decoding $\mathrm{Ca}^{2+}$ signals, because of their ability to rapidly and transiently accumulate $\mathrm{Ca}^{2+}$ (Drago et al. 2012). In animal cells mitochondria were the first intracellular organelles to be associated with $\mathrm{Ca}^{2+}$ handling, and well before the identification of the MCUC components, their ability to rapidly sense $\mathrm{Ca}^{2+}$ signals and to act as localized buffers with a high capacity in the proximity of PM and ER $\mathrm{Ca}^{2+}$ channels/transporters has been proven (Rizzuto et al. 2012). Indeed, mitochondrial $\mathrm{Ca}^{2+}$ uptake, by impacting on local calcium concentrations and on the calciummediated feedback mechanism known to modulate the activity of $\mathrm{Ca}^{2+}$ channels, influences the frequency and amplitude of cytosolic calcium signals. For example, calcium flux across both the PM/ER-located calcium release 
induced calcium channel CRAC (Orai1/Stim1) and ERlocated inositol-1,4,5-trisphosphate receptor is influenced by the physical vicinity of mitochondria. This proximity, sustained by specific contacts, the so-called MAMs (mitochondria-associated membranes) via chaperones such as sigma receptor 1 , in turn sets the extent and duration of the mitochondrial calcium increase. In addition, especially in large cells, recruitment of mitochondria to specific regions seems to be important for constraining $\mathrm{Ca}^{2+}$ signals to defined cell domains. As a result, mitochondrial calcium uptake has been shown at least in vitro to govern numerous patho-physiological processes ranging from insulin secretion, neuronal excitotoxicity and cardiomyocyte function to tumorigenesis. The reader is advised to consult excellent, recent reviews on this topic (e.g., Rizzuto et al. 2012; Foskett and Philipson 2015).

The mitochondrial calcium uniporter $\mathrm{MCU}$, which mediates uptake of this ion into the mitochondria, actively sequesters cytosolic calcium. Significant advances in identifying the molecular players of the mitochondrial $\mathrm{Ca}^{2+}$ handling machinery have been achieved only during the last decade. The finding that a highly $\mathrm{Ca}^{2+}$ selective ion channel, displaying a very small conductance of only 5 $\mathrm{pS}$ in $100 \mathrm{mM} \mathrm{Ca}^{2+}$ in vitro recapitulated the key characteristics observed for the mammalian mitochondrial uniporter in classical bioenergetic experiments, represented a milestone toward the molecular identification of the uniporter (Kirichok et al. 2004). The MitoCarta database, containing more than 1000 mitochondrial proteins (Pagliarini et al. 2008), then provided the basis for the identification of several mitochondrial calcium uniporter complex (MCUC) components in mammals, including the central pore-forming protein $\mathrm{MCU}$ (mitochondrial calcium uniporter; De Stefani et al. 2011; Baughman et al. 2011). At the current stage, MCUC appears to include at least of the pore-forming protein $\mathrm{MCU}$, an $\mathrm{MCU}$ paralog (MCUb), the essential MCU regulator (EMRE), the regulatory MICU proteins and, possibly, the mitochondrial calcium uniport regulator 1 (MCUR1) in mammals (De Stefani et al. 2015), unlike in other systems containing a more simplified MCUC (Wagner et al. 2016). This complex composition in mammals may be the reason why it is still unresolved how matrix $\mathrm{Ca}^{2+}$ transients are shaped in vivo. What is known from experiments in cells is that $\mathrm{Ca}^{2+}$ elevations in the mitochondrial matrix stimulate respiration and ATP synthesis (Denton 2009). $\mathrm{Ca}^{2+}$ overload, by contrast, can trigger cell death (Duchen 2000). Increased biosynthesis rates of ATP rely on the activation of three mitochondrial dehydrogenases by $\mathrm{Ca}^{2+}$ (McCormack et al. 1990). Pyruvate dehydrogenase (PDH) (Denton et al. 1972), NAD-isocitrate dehydrogenase (NAD-ICDH) (Denton et al. 1978) and oxoglutarate dehydrogenase (OGDH) (McCormack and Denton 1979) are activated by physiologically relevant
$\mathrm{Ca}^{2+}$ concentrations $(100 \mathrm{nM}$ and $1 \mu \mathrm{M})$ in mitochondria isolated from mammalian tissues (Denton and McCormack 1980; Denton et al. 1980), and phosphorylation of PDH is thought to be modulated by the calcium-sensitive phosphatase PDP1. $\mathrm{Ca}^{2+}$ elevations in intact cells result in NAD(P) reduction (Duchen 1992, Pralong et al. 1992), supporting a central role for $\mathrm{Ca}^{2+}$-dependent regulation of mitochondrial metabolism. PDH activity is regulated through reversible, calcium-dependent phosphorylation (Holness and Sugden 2003; Tovar-Mendez et al. 2003). The mitochondrial $\left[\mathrm{Ca}^{2+}\right]$ increase evoked by a cytosolic $\left[\mathrm{Ca}^{2+}\right]$ rise leads to an enhanced oxidative phosphorylation as well and boosts ATP production. Knock-out of the MCUC regulator MICU1 that results in an increased resting state level of $\mathrm{Ca}^{2+}$ in the mitochondrial matrix accordingly alters the PDH phosphorylation state in cultured cells (Mallilankaraman et al. 2012). In addition, lower levels of basal matrix calcium in the $\mathrm{MCU}^{-/-}$mice led to markedly increased levels of PDH phosphorylation in these animals (Pan et al. 2013), although the animal model used in this study is debated especially in view of the modest phenotype and of the fact that viable mice could be obtained only in a mixed genetic background (see, e.g., Pendin et al. 2014). The consensus view is that conditional and inducible, tissue-specific knockout models, as well as viral-based gene-delivery systems, will be needed to conclusively assess the real physiological impact of mitochondrial calcium homeostasis in vivo.

A few recent in vivo studies in fact demonstrate that mitochondrial calcium homeostasis is crucial for regulation of metabolism and its alterations are linked to pathologies. Genetic manipulation of MCU in lower organisms such as Zebrafish (Prudent et al. 2013) and Trypanosome brucei (Huang et al. 2013) resulted in major developmental and energetic defects. In humans, homozygous patents carrying a loss-of-function mutation of MICU1 are characterized by myopathy, cognitive impairment and extrapyramidal movement disorder (Logan et al. 2014), along with an increased agonist-induced mitochondrial $\mathrm{Ca}^{2+}$ uptake at low cytosolic $\mathrm{Ca}^{2+}$ concentrations and a decreased cytosolic $\mathrm{Ca}^{2+}$ signal. However, at least under resting conditions, the fibroblasts from affected individuals do not display defects in overall cellular metabolic function, but chronic elevation of the mitochondrial matrix $\mathrm{Ca}^{2+}$ load seems to lead to moderate mitochondrial stress, resulting in fragmentation of the mitochondrial network. In another work, postnatal manipulation of MCU levels in mice (by using adeno-associated virus-mediated gene transfer) demonstrated the contribution of MCUC to the regulation of skeletal muscle tropism. MCU overexpression or downregulation caused muscular hypertrophy or atrophy, respectively, likely independently of metabolic alterations, but dependent on a novel $\mathrm{Ca}^{2+}$ dependent mitochondria-to-nucleus signaling pathway via 
transcriptional regulators (Mammucari et al. 2015). Finally, in mice with myocardial MCU inhibition by transgenic expression of a dominant-negative (DN) MCU, a strong correlation among MCU function, MCU-enhanced oxidative phosphorylation and correct pacemaker cell function has been found (Wu et al. 2015).

Besides its physiological role for muscle function, MCU has also been implicated in cancer-related processes, in particular in the control of metastasis. Recently, Hall and colleagues (Hall et al. 2014) found that breast cancer patient outcomes were negatively correlated with increased $\mathrm{MCU} \mathrm{Ca}^{2+}$ conducting pore subunit expression and decreased MICU1 regulatory subunit expression. However, they showed that a widely used breast cancer cell line did not require MCU or MICU1 activity for survival in contrast to cervical, colon and prostate cancer-derived cells. Our research in a publically available database suggests that indeed expression of MCU is often altered only slightly in tumoral tissues, in accordance with previous findings (Davis et al. 2013) (Table 2). On the other hand, Tang et al. (2015) revealed that MCU expression correlates with metastasis and invasiveness of breast cancer. MCU inhibition by ruthenium red or MCU silencing by siRNA abolished migration of breast cancer cells and reduced serum- or thapsigargin (TG)-induced store-operated $\mathrm{Ca}^{2+}$ entry (SOCE). Serum-induced migrations in these MDAMB-231 cells were blocked by SOCE inhibitors, suggesting that MCU plays a critical role in breast cancer cell migration by regulating SOCE (Tang et al. 2015). In an independent study, $M C U$ expression has been related to breast tumor size and lymph node infiltration. Indeed, in an MDA-MB-231 xenograft model, ablation of MCU induced a reduction in tumor growth and metastasis formation. The mechanism proposed to account for slower tumor progression in MCU-lacking cells envisions reduction in mitochondrial ROS production and via HIF-1alpha and expression of its target genes, in turn inducing a (Tosatto et al. 2016) a decrease in cancer progression genes. In this work, HIF-1alpha has been demonstrated to be a major effector of MCU, since rescuing HIF-1alpha expression the cells restored the tumor cells' ability to migrate. Finally, it has been proposed that a small molecule, AG311, shown to retard tumor growth and to reduce lung metastases, might induce breast cancer cell death by activating MCU, although direct proof is missing (Bastian et al. 2015).
In summary, there is an urgent need to identify pharmacological agents able to impact mitochondrial calcium uptake via their specific action on MCUC components, since the so-far used Ruthenium Red and lanthanides are wide-spectrum modulators. This task could be much greatly helped by structure-activity relationship (SAR) studies. Unfortunately, only the structure of the N-terminal part of MCU has not been resolved up to now (Lee et al. 2015), and a systematic study linking single-point mutations to channel function is also missing. Nevertheless, this issue is of utmost importance, especially in view of the emerging patho-physiological importance of MCUC.

\section{Mitochondrial Kv1.3}

$\mathrm{Kv} 1.3$ is a member of the Shaker family of the potassium channel (Gutman et al. 2005) and is the most expressed channel in the T lymphocytes (Cahalan and Chandy 2009). Plasma membrane Kv1.3 and the other members of the Kv family control the resting and action potential in excitable cells, while in non-excitable tissues it regulates cell volume and proliferation, but also cell death (Armstrong 2003; Gutman et al. 2003; MacKinnon 2003; O'Grady and Lee 2005; Leanza et al. 2014b).

Kv1.3 has been shown to be expressed in brain, lung, thymus, spleen, lymph nodes, fibroblasts, lymphocytes (Szabò et al. 2005), tonsils, macrophages (Leanza et al. 2012b), microglia, oligodendrocytes, osteoclasts, platelets, liver, skeletal muscle, hippocampal neurons (Bednarczyk et al. 2010), astrocytes, and brown and white fat (Gutman et al. 2005; Szabò and Zoratti 2014). Furthermore, Kv1.3 displays an altered expression level in various cancers (Arcangeli et al. 2009; Comes et al. 2015; Bielanska et al. 2009), such as lymphoma (Alizadeh et al. 2000), melanoma (Artym and Petty 2002), glioma (Preussat et al. 2003), breast (Abdul et al. 2003; Jang et al. 2009), prostate (Abdul and Hoosein 2006), gastric (Lan et al. 2005) and colon cancer (Abdul and Hoosein 2002). Kv1.3 was also shown to be present in the mitochondrial inner membrane; in particular, it has been shown to be expressed in the prostate and breast cancer cell lines PC 3 and MCF-7, respectively, and lymphoma and leukemia cells in the mitochondria (Leanza et al. 2013b; Szabo et al. 2015; Gulbins et al. 2010).

Table 2 Oncomine analysis of $C C D C 109 A$ gene in several human cancer tissues. Here are reported only tumors in which gene expression was changed at least twice compare to normal tissues

\begin{tabular}{|c|c|c|c|c|c|}
\hline Gene & Channel & Tissue & Tumor & C vs. N & References \\
\hline \multirow[t]{3}{*}{ CCDC109A } & \multirow[t]{3}{*}{ MCU } & Pancreas & Pancreatic carcinoma & 3.014 & Pei et al. (2009) \\
\hline & & & & 3.577 & Iacobuzio-Donahue et al. (2003) \\
\hline & & Kidney & Papillary renal cell carcinoma & 2.292 & Yusenko et al. (2009) \\
\hline
\end{tabular}


Results from the Oncomine database are reported in Table 3: Kv1.3 is overexpressed in several tumors that affect different organs, such as the kidney, blood, skin, brain and esophagus, at least two fold with respect to the normal tissues. Changes in Kv1.3 expression in cancer cells have been related to epigenetic mechanisms, such as DNA methylation, as demonstrated in pancreatic cancer (Brevet et al. 2009a) and in poorly differentiated breast cancer (Brevet et al. 2009b).

Ten years ago, our group discovered the mitochondrial counterpart (mitoKv1.3) of this channel located in the IMM (Szabò et al. 2005). Other members of $\mathrm{Kv}$ channels have also been described in mitochondria, i.e., Kv1.5 and Kv1.1 (Vicente et al. 2006; Leanza et al. 2013a). MitoKv1.3 mediates an inward potassium flux to the mitochondrial matrix and has a role in the organellar $\mathrm{K}^{+}$cycle that participates in the modulation of coupling between ATP synthesis and mitochondrial respiration, thus contributing to the regulation of several processes including mitochondrial volume, mitochondrial structural integrity and production of ROS (Szabò et al. 2012). Moreover, mitoKv1.3 has an important role during apoptotic cell death (Szabó et al. 2008). In particular, it has been demonstrated that mitoKv1.3 can interact with pro-apoptotic Bax via a critical lysine (lys128) that protrudes into the mitochondrial intermembrane space (Annis et al. 2005) following translocation of Bax to the outer mitochondrial membrane. Point mutation of this lysine into a glutamic acid led to lack of inhibition of mitoKv1.3 and to a switch in the function of Bax, transforming it into an anti-apoptotic protein (Szabò et al. 2011).

We then provided evidence that pharmacological inhibition of mitoKv1.3 by membrane permeant blockers, the psoralens Psora- 4 and PAP-1, and the riminophenazine clofazimine, is sufficient to trigger apoptotic cell death in cancer cells but not in healthy ones (Leanza et al. 2012a, 2013b, 2014a, Szabo et al. 2015). Inhibition of mitoKv1.3 induced a block of the potassium flux into the mitochondria inducing mitochondrial membrane hyperpolarization followed by reduction of the respiratory chain complexes, which causes increased ROS production. ROS can in turn activate both PTP inducing mitochondrial membrane depolarization and favor the detachment of cytochrome $\mathrm{c}$ from the cristae and its release in the cytosol activating intrinsic cell death pathway (Leanza et al. 2015b).

Cell death was detected both in vitro, even with cancer cells lacking pro-apoptotic Bax and Bak, often downregulated in tumors, and in vivo. In particular, clofazimine reduced the tumor volume by $90 \%$ in an orthotopic mouse melanoma model (Leanza et al. 2012a). Furthermore, these compounds acted also on primary tumor B-cells obtained from patients affected by chronic lymphocytic leukemia (CLL), one of the most diffuse forms of leukemia in the Western world. Indeed, in $e x$-in vivo experiments, pathological B-cells underwent cell death while healthy cells from the same patients did not. Importantly, these effects were also obtained with the B-CLL cells that are mutated in p53, or overexpressing anti-apoptotic Bcl-2, and were independent of the currently used prognostic factors (ZAP70, CD38 and hypersomatic mutation) (Leanza et al. 2013b). Moreover, these compounds killed primary tumor B-cells even when they were co-cultured together with mesenchymal stromal cells, which mimic the lymph node micro-environment, favoring the pathological B-cells' survival (Szabo et al. 2015). The selectivity versus cancer cells, according to our experiment-based model, is due to a synergistic effect of mitoKv1.3 inhibition and an increase of ROS: reactive oxygen species are often altered in tumor cells leading them to more easily reach the critical threshold necessary to trigger cell death upon exogenous oxidative insult (Ralph et al. 2010). In contrast, normal cells, even if an increased ROS production is induced, do not reach the threshold and do not undergo apoptosis (Trachootham et al. 2009). Importantly, the fact that clofazimine is a drug that
Table 3 Oncomine analysis of $K C N A 3$ gene in several human cancer tissues. Here are reported only tumors in which gene expression was changed at least twice compare to normal tissues

\begin{tabular}{llllll}
\hline Gene & Channel & Tissue & Tumor & C vs. N & References \\
\hline KCNA3 & Kv1.3 & Kidney & Chromophobe renal cell carcinoma & 4.908 & Jones et al. (2005) \\
& & & Renal pelvis urothelial carcinoma & 4.315 & Jones et al. (2005) \\
& \multirow{2}{*}{ Blood } & Chronic lymphocytic leukemia & 2.368 & Rosenwald et al. (2001) \\
& & & 3.180 & Basso et al. (2005) \\
& & & 2.197 & Haferlach et al. (2010) \\
& & T-cell acute lymphoblastic leukemia & 2.198 & Haferlach et al. (2010) \\
& & Primary effusion lymphoma & 6.402 & Basso et al. (2005) \\
& & Mantle cell lymphoma & 2.924 & Basso et al. (2005) \\
& & Marginal zone B-cell lymphoma & 2.701 & Storz et al. (2003) \\
& Skin & Actinic (solar) keratosis & 2.667 & Nindl et al. (2006) \\
& Brain & Classic medulloblastoma & 2.289 & Pomeroy et al. (2002) \\
& Esophagus & Barrett's esophagus & 2.565 & Hao et al. (2006) \\
\hline
\end{tabular}


is already used in the clinic to treat leprosy and some autoimmune diseases with a very good safety profile (Cholo et al. 2012) leads to the possibility for drug repositioning, i.e., for treating Kv1.3-expressing tumors with this drug.

Interestingly, it has recently been demonstrated that Kv1.3 channels are localized in the nucleus of several types of cancer cells and human brain tissues where they are able to regulate the nuclear membrane potential and activation of transcription factors, such as phosphorylated CREB and c-Fos (Jang et al. 2015). Furthermore, Kv1.3 has been shown to be present also in the cis-Golgi, even if its role in this intracellular membrane and the eventual connection with cancer development have not been investigated yet (Zhu et al. 2014).

\section{Mitochondrial BKCa (KCa1.1)}

The large-conductance calcium- and voltage-activated $\mathrm{K}^{+}$channel BKCa (KCa1.1) is expressed at the plasma membrane of both excitable and non-excitable cells, including sensory and epithelial cells. It is also expressed in the smooth muscle and cardiac muscle, where it is involved in muscle contraction but also in cytoprotection during ischemia/reperfusion. Furthermore, plasma membrane BKCa also has a role in hypertension and cancer cell metastasis (Cui et al. 2009; Sah 1996; Eichhorn and Dobrev 2007; Félétou 2009; Sokolowski et al. 2011). $\mathrm{BKCa}$ has also been revealed in intracellular membranes, such as the nuclear membrane, ER, Golgi and mitochondria (Singh et al. 2012). The existence of mitoBKCa has been proven by electrophysiological experiments, as well as by Western blotting, electron microscopy and immunofluorescence (O'Rourke 2007; Szewczyk et al. 2010; Douglas et al. 2006; Kathiresan et al. 2009; Piwonska et al. 2008; Skalska et al. 2008). MitoBKCa has been observed in the mitochondria of glioma cell lines, astrocytes as well as ventricular cells, skeletal muscle, brain and endothelial cells. The known modulators of the plasma membrane channel also act on the mitoBKCa. These compounds can be divided into activators, such as calcium, diCl-DHAA (Sakamoto et al. 2008), NS1619 (Skalska et al. 2009), 17-estradiol (Ohya et al. 2005) and hypoxia (Cheng et al. 2008), or inhibitors, such as charybdotoxin (Gu et al. 2007; Skalska et al. 2008), iberiotoxin (Cheng et al. 2008, 2011) and paxillin (Heinen et al. 2007a, b), but no drug acting exclusively on the mitochondrial channel is available up to now.

The role of mitoBKCa in pathophysiological conditions seems to consist of the modulation of mitochondrial $\mathrm{Ca}^{2+}$ uptake. Indeed, its opening protects against damage to the heart and other organs caused by ischemia and reperfusion, possibly by preventing calcium overload (O'Rourke 2007; Xu et al. 2002). mitoBKCa has also been associated with cell death, since Bax can inhibit the channel leading to the activation of the MPTP (Cheng et al. 2011). To date, no evidence about a possible role of mitoBKCa in cancer development has been reported, except for a possible role in glioma cell motility after irradiation: BK channel activity is augmented by increasing the open probability but not the number of the channels, which results in activation of CaMKII leading to enhanced glioblastoma cell migration (Steinle et al. 2011).

\section{Mitochondrial IKCa (KCa3.1)}

The intermediate-conductance potassium channel (IKCa or $\mathrm{KCa} 3.1)$ is expressed in various tissues, such as epithelial and endothelial tissues, immune system, sensory neurons and microglia but not in excitable tissues. The IKCa is involved in several physiological processes modulating membrane potential and calcium signaling, including cell proliferation and differentiation in numerous cell types (Szabò and Zoratti 2014). The most known and used blockers are TRAM-34, cyclohexadiene 4 and clotrimazole (Wulff and Castle 2010). IKCa showed a different expression in cancer with respect to normal cells: a possible explanation for this variation could be ascribed to changes at the transcriptional level. The RE1-silencing zinc-finger transcription factor (REST) binds to a 21-bp DNA element (RE1) within the regulatory region of its target genes, repressing gene expression. REST expression can be abnormally regulated in cancer cells (e.g., Shimojo et al. 2013). There are more than 1300 genes that contain an RE1 element, including genes that encode proteins of fundamental importance for cell function such as ion channels. A reduced expression of REST can result in the transcriptional activation of $\mathrm{KCa} 3.1$, as observed in vascular cells (Cheong et al. 2005). Mutations that compromise REST transcriptional repression have been associated with different cancers, e.g., with childhood renal cancer (Mahamdallie et al. 2015). Thus, one intriguing possibility is that expression of ion channels in general, including that of IKCa in cancer cells, is linked to regulation by functionally altered REST.

An intracellular localization for the IKCa (mitoIKCa) in the inner mitochondrial membrane of human colon carcinoma and HeLa cells, as well as in mouse embryonic fibroblasts, has been demonstrated by electrophysiology and Western blotting (De Marchi et al. 2009; Sassi et al. 2010). The plasma membrane channel and mitochondrial one seem to have the same structure and physiological proprieties, since also the mitoIKCa is inhibited by TRAM-34 and clotrimazole.

The role of mitoIKCa in the IMM has not been investigated in detail, but it is expected to be similar to the one hypothesized for the mitoKv1.3 and other mitochondrial 
potassium channels, i.e., a contribution to the regulation of the organelle membrane potential, volume and ROS production. A possible role for the mitoIKCa was also postulated during cell death, even if this channel, contrarily to mitoBKCa and mitoKv1.3, did not interact with Bax. Nevertheless, a possible role of mitoIKCa in inducing cell death has to be verified, since a connection between IKCa channels and the intrinsic apoptotic pathway has been observed (McFerrin et al. 2012). Furthermore, while TRAM-34 alone was not able to induce cell death when used at the micromolar range, it increased the sensitivity of melanoma cells to TRAIL treatment (Quast et al. 2012).

\section{Mitochondrial TWIK-related acid-sensitive $\mathrm{K}^{+}$ channel-3 (TASK-3)}

The two-pore $\mathrm{K}^{+}(\mathrm{K} 2 \mathrm{P})$ channels, to which the Tandem of P-domains weakly inward rectifying $\mathrm{K}^{+}$(TWIK)-related acid sensitive $\mathrm{K}^{+}$channel 3 (TASK-3) belongs, is the most recently identified group among the $\mathrm{K}^{+}$channels. K2P channels are 'leak' $\mathrm{K}^{+}$channels that set the resting membrane potential and regulate cell excitability (Felipe et al. 2006; Bayliss and Barrett 2008). TASK-3 is normally found in the adrenal cortex, gastrointestinal tract, neuronal tissue and salivary glands (Bayliss and Barrett 2008; Kovacs et al. 2005) and is modulated by alterations in extracellular $\mathrm{pH}$ and by anaesthetic agents; it plays a role in aldosterone secretion (Bayliss and Barrett 2008; Bayliss et al. 2003; Ekhterae et al. 2003; Patel and Lazdunski 2004). Altered TASK-3 expression has already been defined in several types of cancer, i.e., breast cancer, and the gene encoding TASK-3 (KCNK9) was found to be overexpressed by 5to $>100$-fold in $44 \%$ of tumors (Mu et al. 2003). TASK-3 expression has also been identified in mitochondria of melanoma, keratinocytes (Rusznák et al. 2008) and healthy intestinal epithelial cells (Kovacs et al. 2005). Furthermore, this channel is also expressed in lung, colon and ovarian cancers (Felipe et al. 2006; Kim et al. APMIS 2004; Pocsai et al. 2006; Innamaa et al. 2013). Silencing the expression of TASK-3 resulted in compromised mitochondrial function, i.e., mitochondrial membrane depolarization, and reduced cell survival inducing apoptotic cell death in WM35 and A2058 melanoma cells (Kosztka et al. 2011; Nagy et al. 2014). Two aspects linked TASK-3 to cancer development or treatment: (1) observed migration and invasion-reducing effects of TASK-3 overexpression in breast cancer cells (Lee et al. 2012) and (2) increased apoptosis induced by TASK-3 blockers (zinc and methanandamide) in ovarian carcinoma (Innamaa et al. 2013). Further investigation will be necessary to understand whether these effects are related to the mitochondrial channel expression and whether it is possible to pharmacologically regulate mtTASK-3 causing tumor cell death. Since no highly specific mtTASK-3 modulators are available, this aim is difficult to investigate, and the only advance in this field is represented by dihydropyrrolo[2,1- $\alpha]$ isoquinolines (DPIs) compounds, which are able to inhibit TASK channels and could be possible candidates for developing new specific inhibitors (Noriega-Navarro et al. 2014).

\section{Mitochondrial magnesium channel Mrs2}

Mitochondria not only store calcium, but also take up magnesium to maintain the optimal cytosolic $\mathrm{Mg}^{2+}$ concentration (0.5-0.7 mM) (Kubota et al. 2005). $\mathrm{Mg}^{2+}$ can be accumulated inside the mitochondria via the $\mathrm{Mg}^{2+}$-selective channel of the inner mitochondrial membrane (Kolisek et al. 2003), which takes advantage of the driving force produced by the mitochondrial membrane potential and is feedback regulated by the increasing $\mathrm{Mg}^{2+}$ concentration in the matrix (Khan et al. 2010). An early increase in cytosolic $\mathrm{Mg}^{2+}$, which also favors cytochrome c release, occurs during apoptotic cell death (Chien et al. 1999; Kim et al. 2000). Moreover, knockdown of the mitochondrial magnesium channel (Mrs2) caused cell death by inducing loss of respiratory complex I and mitochondrial membrane depolarization (Piskacek et al. 2009). On the contrary, an upregulation of Mrs2 has been observed in parental human gastric adenocarcinoma cell lines, indicating that high expression of Mrs2 may protect against death (Chen et al. 2009; Wolf and Trapani 2009). In agreement, an augmented expression of the $m r s 2$ gene has been reported by comparing normal and cancer organs as shown in Table 4: a general increase of around two-three-fold (but in testis tumor a 17-fold increase) has been observed in blood, skin, ovarian, kidney, breast, lung and bladder tumors when compared to the normal tissues, meaning that it would be worthwhile to further deepen our understanding of the possible role of mitochondrial $\mathrm{Mg}^{2+}$ fluxes in cancer development (see Table 4 and the references therein).

\section{Mitochondrial uncoupling protein UCP}

The Uncoupling protein (UCP) family is constituted by five members and belongs to the mitochondrial anion-carrier proteins (Krauss et al. 2005). UCPs are inner mitochondrial membrane proteins involved in the re-entry of protons into the mitochondrial matrix, partially dissipating the electrochemical gradient and therefore the mitochondrial membrane potential. As a consequence, UCP2 regulates mitochondrial ROS production as well. UCP-2 is ubiquitously expressed in different tissues, including skeletal muscle and $\beta$-cells, and it is overexpressed in numerous tumors, such as breast, ovarian, bladder, esophagus, testicular, colorectal, kidney, pancreatic, lung and prostate cancers and leukemia (Leanza et al. 2014b). 
Table 4 Oncomine analysis of MRS2 gene in several human cancer tissues. Here are reported only tumors in which gene expression was changed at least twice compare to normal tissues

\begin{tabular}{|c|c|c|c|c|c|}
\hline Gene & Channel & Tissue & Tumor & C vs. N & References \\
\hline \multirow[t]{24}{*}{ MRS2 } & \multirow[t]{24}{*}{ Mrs2 } & \multirow[t]{8}{*}{ Testis } & \multirow[t]{2}{*}{ Testicular embryonal carcinoma } & 17.178 & Skotheim et al. (2005) \\
\hline & & & & 9.762 & Korkola et al. (2006) \\
\hline & & & \multirow[t]{2}{*}{ Testicular seminoma } & 3.812 & Skotheim et al. (2005) \\
\hline & & & & 3.281 & Korkola et al. (2006) \\
\hline & & & Testicular intratubular germ cell neoplasia & 2.754 & Skotheim et al. (2005) \\
\hline & & & \multirow[t]{2}{*}{ Testicular yolk sac tumor } & 2.213 & Skotheim et al. (2005) \\
\hline & & & & 4.199 & Korkola et al. (2006) \\
\hline & & & Testicular teratoma & 2.006 & Skotheim et al. (2005) \\
\hline & & \multirow[t]{3}{*}{ Skin } & Skin basal cell carcinoma & 3.487 & Riker et al. (2008) \\
\hline & & & Cutaneous melanoma & 3.469 & Riker et al. (2008) \\
\hline & & & Skin squamous cell carcinoma & 2.056 & Riker et al. (2008) \\
\hline & & Ovarian & Ovarian serous adenocarcinoma & 3.105 & Yoshihara et al. (2009) \\
\hline & & \multirow[t]{2}{*}{ Kidney } & Papillary renal cell carcinoma & 3.070 & Yusenko et al. (2009) \\
\hline & & & Chromophobe renal cell carcinoma & 2.283 & Yusenko et al. (2009) \\
\hline & & \multirow[t]{3}{*}{ Breast } & Ductal breast carcinoma & 2.775 & Richardson et al. (2006) \\
\hline & & & Ductal breast carcinoma in situ & 2.049 & Ma et al. (2009) \\
\hline & & & Invasive breast carcinoma & 2.376 & Finak et al. (2008) \\
\hline & & \multirow[t]{4}{*}{ Blood } & T-cell childhood acute lymphoblastic leukemia & 2.517 & Coustan-Smith et al. (2011) \\
\hline & & & B-cell childhood acute lymphoblastic leukemia & 2.036 & Coustan-Smith et al. (2011) \\
\hline & & & Anaplastic large cell lymphoma & 2.400 & Piccaluga et al. (2007) \\
\hline & & & Angioimmunoblastic T-cell lymphoma & 2.023 & Piccaluga et al. (2007) \\
\hline & & Lung & Pleural malignant mesothelioma & 2.458 & Gordon et al. (2005) \\
\hline & & \multirow[t]{2}{*}{ Bladder } & Superficial bladder cancer & 2.440 & Dyrskjøt et al. (2004) \\
\hline & & & Infiltrating bladder urothelial carcinoma & 2.073 & Dyrskjøt et al. (2004) \\
\hline
\end{tabular}

UCP2 has been proposed to impact cell survival by decreasing the formation of mitochondrial superoxide production by tuning the proton leak and thus the mitochondrial membrane potential (Baffy 2010; Baffy et al. 2011; Basu Ball et al. 2011; Deniaud et al. 2012). Indeed, UCP2 overexpression protects against ROS production and increases the apoptotic threshold for cancer cell survival (Zhang et al. 2007), while UCP2 knockdown or pharmacological inhibition leads to an increase in mitochondrial ROS, as observed in UCP2 knockout mice (Arsenijevic et al. 2000). Moreover, UCP2 downregulation or inhibition triggers an ROS-mediated autophagy in pancreatic adenocarcinoma cells (Dando et al. 2013).

UCP2 overexpression has been observed after oxidative stress induced by respiratory chain inhibitors (Giardina et al. 2008) and has been related to the development of breast cancer in an orthotopic model (Ayyasamy et al. 2011). Furthermore, UCP-2 overexpression was correlated with the Warburg phenotype (Samudio et al. 2008). Additionally, UCP2 was proposed to catalyze an exchange of malate, oxaloacetate and aspartate for phosphate; it exports $\mathrm{C} 4$ metabolites from mitochondria to the cytosol in vivo, providing evidence that UCP2 reduces mitochondrial oxidation of glucose and enhances glutaminolysis. These results postulate a unique regulatory mechanism in cell bioenergetics and explain the significance of UCP2 levels in metabolic reprogramming occurring under various physiopathological conditions (Vozza et al. 2014).

Importantly, UCP2 overexpression prevented the deathinducing effect of chemotherapy in different cancer cell lines: indeed, treatment with gemcitabine stimulates UCP2 mRNA production, suggesting a role of mitochondrial uncoupling in the resistance to this chemotherapeutic agent, and pointed out the possible synergistic antiproliferative effect of coupling gemcitabine treatment and UCP2 inhibition (Derdak et al. 2008; Dalla Pozza et al. 2012; Yu et al. 2015a). Onconase, a member of the RNase super-family, is able to inhibit UCP2 and manganese-dependent superoxide dismutase (MnSOD), thus triggering mitochondrial superoxide ion production leading to autophagy (Fiorini et al. 2015). Similarly, a decrease in cell viability and clonogenicity, in addition to an increase in $\Delta \Psi \mathrm{m}$, ROS production, apoptosis and autophagy, was induced in breast cancer cells after both UCP2 inhibition by siRNA and cytotoxic 
treatments by tamoxifen (Gabriel Pons et al. 2015). Likewise, MiR-214 sensitizes breast cancer cells to both tamoxifen and fulvestrant treatment by targeting UCP2 (Yu et al. 2015b). Finally, UCP3 has been linked to clear cell renal cell carcinoma: it has been proposed that inhibition of UCP3 by ADP might contribute to the setting of the endogenous mitochondrial membrane potential (Lim et al. 2015).

In summary, modulation of oxidative stress in cancer cells is a powerful tool to kill or at least sensitize them to chemotherapeutic treatments, as has been observed with mitoKv1.3. In this scenario, a primary role could be attributed to UCP proteins, especially to UCP2 and UCP3.

\section{Intracellular chloride channel CLIC-4}

An emerging class of chloride-permeable channels involved in cancer development is the intracellular chloride channels (CLICs). In particular, chloride intracellular channel 4 (CLIC4) is the most well-characterized member of a family of channel proteins that is highly conserved from Caenorhabditis elegans to humans. The intracellular CLIC4/ mtCLIC has both soluble and membrane-inserted forms and can be localized in different subcellular compartments, such as the mitochondrial inner membrane (FernándezSalas et al. 1999), cytoplasm, ER membrane, and nucleus. The expression of the CLIC4 transcript is regulated by p53 and tumor necrosis factor $\alpha(\mathrm{TNF} \alpha)$, and clic4 is a direct response gene for both c-myc and p53, two mediators of cancer pathogenesis in multiple tumor sites (Peretti et al. 2015).

CLIC4 overexpression induced apoptotic cell death mediated by loss of the mitochondrial membrane potential, cytochrome c release and caspase activation (FernándezSalas et al. 2002). On the other hand, inhibition of CLIC4 expression triggered mitochondrial apoptosis under starvation and enhanced autophagy in human glioma cells (Zhong et al. 2012; Xu et al. 2013). Marked changes in expression and subcellular localization of CLIC4 occur early in tumorigenesis: (1) CLIC4 expression was reported to be a marker of colon cancer stem cells and is associated with a poor prognosis, (Deng et al. 2014); (2) reduced CLIC4 expression and nuclear translocation, following cellular stress conditions, e.g., DNA damage, senescence and metabolic alterations, is associated with the altered redox state, and CLIC4 acts as an important suppressor of cutaneous squamous cell cancer development and progression (Suh et al. 2012); (3) KRAS-mediated downregulation of CLIC4 may promote cancer carcinogenesis in a specific fraction of lung cancers (Okudela et al. 2014). Moreover, circulating CLIC4 was identified as a biomarker for epithelial ovarian cancer (Tang et al. 2013). Thus, in addition to an important function in cancer pathogenesis as a tumor suppressor, CLIC4 is emerging as a potential biomarker to monitor tumor progression and recurrence in multiple human cancers.

\section{Intracellular potassium channel Kv10.1}

A surprising localization of the human ether à-go-go1 protein (Eag1 or Kv10.1), a potassium voltage-gated channel subfamily $\mathrm{H}$ member 1, has been described in the nuclear inner membrane (Chen et al. 2011). There, the channel seems to be involved in setting the nuclear $\mathrm{K}^{+}$concentration thereby affecting gene expression, as postulated also for the nuclear Kv1.3. Even if expressed in the plasma membrane, Kv10.1 is also rapidly internalized to lysosomes (Kohl et al. 2011), as demonstrated also by patch clamp measures (Wang et al. 2012).

An increased expression of Kv10.1 can be triggered by the tumor suppressor p53, as observed in glioblastoma (Bai et al. 2013), and the transcription factor E2F1 (Lin et al. 2011). Overexpressed Kv10.1 controls cancer cell migration and proliferation by interactions with RAB proteins (Ninkovic et al. 2012), cortactin (CTTN) and focal adhesion kinase (FAK) (Herrmann et al. 2012) as well as through calcium signaling (Hammadi et al. 2012) and an altered response to hypoxia (Downie et al. 2008). Overexpression by genomic amplification has been implicated as a mechanism of Kv10.1 involvement in a small proportion of colon $(3.4 \%)$ and head and neck (15\%) cancers (Pardo and Stühmer 2014).

Eag1 is not detectable in healthy tissues except the brain, but its overexpression, not discriminating between the plasma membrane and intracellular channels, has been detected at a very high rate $(>75 \%)$ in several tumors: breast, renal and cervical carcinoma cell lines, as well as in different human malignancies, for instance, colorectal and cervical cancer, soft tissue sarcomas, acute myeloid leukemia, esophageal and gastric cancer, head and neck carcinomas, ovarian, breast, lung and prostate cancer and glioblastoma (Martínez et al. 2015 and references therein). Importantly, Kv10.1 expression correlates with poor prognosis in fibrosarcoma, ovarian carcinoma, acute myeloid leukemia (AML) and colon, head and neck cancer (Pardo and Stühmer 2014).

Furthermore, Kv10.1 transfection in healthy cells induces transformation and leads the transfected cells to develop invasive tumors in vivo: this was the first observation of the oncogenic capacity of a potassium channel (Pardo et al. 1999). Interestingly, a Kv10.1 mutant that lacks potassium permeability reduces, but does not abolish tumorigenesis (Downie et al. 2008; Hegle et al. 2006). Despite all these observations, the exact contribution of the intracellular Eag1 to cancer cell survival remains to be determined. 


\section{Intracellular Transient Receptor Potential Channel (TRPs)}

The transient receptor potential (TRP) channel superfamily is one of the largest families of cation channels (Nilius and Owsianik 2011). The TRP family is constituted by 28 members, divided into subfamilies, which are TRPC (canonical), TRPM (melastatin), TRPP (polycystin), TRPV (vanilloid), TRPML (mucolipin) and TRPA (ankyrin-like) (Nilius 2007). Among them, the intracellularly located channels that are related to cancer development and progression identified so far are TRPM8 and TRPC1.

The calcium-permeable TRPM8 is located in the endoplasmatic reticulum (ER) membrane and is overexpressed in several tumors (Zhang and Barritt 2004). TRPM8 trafficking is mediated during carcinogenesis by interaction and consequent regulation by TRPM8 channel-associated factor 1 and 2 (TCAF-1 and TCAF-2). In particular, TCAF-1 is more expressed in the early tumor stages favoring cancer development, while its expression as well as that of TRPM8 is reduced during the tumor spreading with metastasis (Gkika et al. 2015). Intracellular TRPM8 mediates the decrease in $\mathrm{Ca}^{2+}$ concentration inside the ER and favors the resistance to apoptotic cell death (Bidaux et al. 2007). As mentioned above, an increase in intracellular $\mathrm{Ca}^{2+}$ leads to modulation of the signaling pathways and to transcription of genes that mediate the cellular responses to mitogens and chemoattractants.

TRPM8 expression in normal conditions is tissue-selective, while when TRPM8 is abnormally expressed, it has been observed in several different cancer tissues, such as prostatic, pancreatic, breast and colorectal ones, in urinary bladder and oral squamous cells, and in lung carcinoma, melanoma, neuroblastoma and osteosarcoma (Yee 2015). In particular, expression of TRPM8 in breast carcinoma correlates with the histological grade, Ki-67, tumor size and expression of the estrogen receptor. These findings suggest that TRPM8 channels play a pivotal role in the development and growth of mammary tumors (DhenninDuthille et al. 2011; Chodon et al. 2012; Liu et al. 2014). Experimental data demonstrated that TRPM8 channels play important roles in general in cancer cells, in particular in their proliferation, survival, migration, invasion and neurosecretion. For example, the regulation of proliferation in cancer cell lines has been proven by siRNA experiments, in which downregulation of TRPM8 caused the reduction of prostatic and osteosarcoma cancer cell proliferation and cell cycle progression (Valero et al. 2012; Wang et al. 2014). On the other hand, in lung carcinoma, the ectopic expression of TRPM8 favors cell propagation (Du et al. 2014). These data suggest a tumor-specific role of TRPM 8 in proliferation. Furthermore, several in vivo studies have linked TRPM8 to cancer growth and metastasis (Yee 2015). The aberrant overexpression of TRPM8 in tumors and its proliferative and invasive roles suggest a future development of the TRPM8 channel as a prognostic/predictive biomarker and a therapeutic target in oncology.

Another member of this superfamily located in the ER is TRPC1. This was the first and most studied member in the context of cancer, being involved in several features of cancer cells, such as cell fate and motility (Shapovalov et al. 2016). This channel has a specific regulation in cancer, also depending on the stage of malignant transformation: the TRPC1 expression level decreases with the progression of the prostate cancer from the androgen-dependent to androgenin dependent phase (Nilius et al. 2007). The role of TRPC1 in cancer progression is predominantly related to cell motility. In particular, inhibition of expression and/or activity in nasopharyngeal carcinoma led to reduced adhesion and invasiveness of cancer cells (He et al. 2012). Furthermore, pharmacological inhibitors, such as SKF96365, 2-APB and MRS1845, or siRNA against TRPC1 was able to suppress human malignant glioma proliferation (Bomben and Sontheimer 2010). Similar effects have also been found in a lung carcinoma cell line, in which TRPC1 ablation by siRNA induced blocking of cell growth due to $\mathrm{G} 0$ / G1 cell cycle arrest (Bomben et al. 2011).

\section{Intracellular IP3 receptors}

The two major families of $\mathrm{Ca}^{2+}$ channels involved in the release of this cation from the ER include the inositol 1,4,5-trisphosphate receptors (IP3Rs) and ryanodine receptors (RyRs). In cancer cells, $\mathrm{Ca}^{2+}$ mobilization has been observed to contribute to tumor progression, and increasing numbers of studies indicate the relevance of IP3Rs to cancer. (Prevarskaya et al. 2011; Roderick and Cook 2008; Lee et al. 2011; Monteith et al. 2012). Indeed, type 1 IP3R (i.e., IP3R1) expression is reduced and type 3 IP3R (i.e., IP3R3) expression is increased in human glioblastoma tissues compared to normal human brain, and inhibition of IP3R3 by caffeine reduces the migration, invasion and survival of glioblastoma cells (Kang et al. 2010). Similar effects as the one induced by caffeine have been observed in breast cancer cells in the presence of $17 \beta$-estradiol (E2) (Szatkowski et al. 2010). Increased IP3R3 expression was also related to aggressiveness in colorectal cancer: high levels of IP3R were associated with increased metastasis in the lymph nodes and liver and a decreased 5-year survival (Shibao et al. 2010). Moreover, changes in IP3R1 have been implicated in the biological properties of the tumors: for example, cisplatin-induced downregulation of IP3R1 expression was found to be associated with the acquisition of cisplatin 
resistance in bladder cancer cell lines (Tsunoda et al. 2005). Furthermore, Bcl-2 family proteins, which have pro- and anti-apoptotic functions, directly bind to different sites on IP3Rs and impact IP3R function, suggesting that IP3R is an important hub for the action of $\mathrm{Bcl}-2$ family proteins in various physiological and pathological settings including tumor progression (Seo et al. 2015; Oakes et al. 2005; Letai 2008). In addition, other proto-oncogenes as well as tumor suppressors, such as Akt/protein kinase B (PKB) (Chan and Tsichlis 2001), Bax inhibitor-1 (BI-1) (Li et al. 2007a; Eckenrode et al. 2010) and K-ras-induced actin-interacting protein (KRAP) (Fujimoto et al. 2011), modulate cancer development by acting on $\mathrm{Ca}^{2+}$ fluxes mediated by the IP3Rs (Akl and Bultynck 2013). Currently, little is known about what specific players of $\mathrm{Ca}^{2+}$ signaling contribute to the altered $\mathrm{Ca}^{2+}$ mobilization in cancer cells and how $\mathrm{Ca}^{2+}$ signaling cross-talks with well-known cancer pathways, such as the Ras/Raf/MAPK pathway (Dhillon et al. 2007). Recently, a paper has connected the Ras signaling pathway, often deregulated in cancer (Downward 2003), to the IP3Rmediated $\mathrm{Ca}^{2+}$ release pathway. Indeed, oncogenic K-Ras inhibited IP3-induced $\mathrm{Ca}^{2+}$ release from the ER by remodeling of IP3R isoform composition in a human colorectal cancer cell line harboring the K-Ras mutant allele (G13D) (Pierro et al. 2014). A further link between K-Ras and IP3R is suggested by the finding that $\mathrm{K}$-the GTP-bound active form of K-Ras4B-forms a ternary complex with IP3R and $\mathrm{Bcl}-\mathrm{xL}$ and promotes cell death, indicating that IP3R is a novel effector of K-Ras4B. (Sung et al. 2013).

Finally, IP3Rs have also been shown to interact with other ion channels. Indeed, IP3R3 is able to favor breast cancer cell proliferation by co-localizing and directly interacting with BKCa channels, but only in cancerous cells and not in the healthy ones (Mound et al. 2013).

Acknowledgments We are grateful to the Italian Association for Cancer Research (AIRC Grant IG 11814 to IS) and to the Italian Ministry of Education (PRIN Project 2010CSJX4F to I.S.) for financial support. I.S. is grateful to the Iontrac Marie Curie Training Network (FP7-PEOPLE-2011-ITN Grant Agreement No. 289648). L.L. is a recipient of a Young Investigator Grant of the University of Padova (GRIC12NN5G) and EMBO Short-Term Fellowship (ASTF 233-2014).

Open Access This article is distributed under the terms of the Creative Commons Attribution 4.0 International License (http://creativecommons.org/licenses/by/4.0/), which permits unrestricted use, distribution, and reproduction in any medium, provided you give appropriate credit to the original author(s) and the source, provide a link to the Creative Commons license, and indicate if changes were made.

\section{References}

Abdul M, Hoosein M (2002) Voltage-gated potassium ion channels in colon cancer. Oncol Rep 9:961-964
Abdul M, Hoosein N (2006) Reduced Kv1.3 potassium channel expression in human prostate cancer. J Membr Biol 214:99-102

Abdul M, Santo A, Hoosein N (2003) Activity of potassium channelblockers in breast cancer. Anticancer Res 23:3347-3351

Abu-Hamad S, Sivan S, Shoshan-Barmatz V (2006) The expression level of the voltage dependent anion channel controls life and death of the cell. Proc Natl Acad Sci U S A 103:5787-5792

Abu-Hamad S, Zaid H, Israelson A, Nahon E, Shoshan-Barmatz V (2008) Hexokinase-I protection against apoptotic cell death is mediated via interaction with the voltage-dependent anion channel-1: mapping the site of binding. J Biol Chem 283:13482-13490

Abu-Hamad S, Arbel N, Calo D, Arzoine L, Israelson A, Keinan N et al (2009) The VDAC1 N-terminus is essential both for apoptosis and the protective effect of anti-apoptotic proteins. J Cell Science 122:1906-1916

Advani PP, Paulus A, Masood A, Sher T, Chanan-Khan A (2011) Pharmacokinetic evaluation of oblimersen sodium for the treatment of chronic lymphocytic leukemia. Exp Opin Drug Metab Toxicol 7:765-774

Akl H, Bultynck G (2013) Altered $\mathrm{Ca}^{2+}$ signaling in cancer cells: proto-oncogenes and tumor suppressors targeting IP3 receptors. Biochim Biophys Acta 1835:180-193

Alavian KN, Beutner G, Lazrove E, Sacchetti S, Park HA, Licznerski $P$ et al (2014) An uncoupling channel within the c-subunit ring of the F1FO ATP synthase is the mitochondrial permeability transition pore. Proc Natl Acad Sci USA 111:10580-10585

Alizadeh AA, Eisen MB, Davis RE, Ma C, Lossos IS, Rosenwald A et al (2000) Distinct types of diffuse large B-cell lymphoma identified by gene expression profiling. Nature 403:503-511

Andersen AP, Moreira JM, Pedersen SF (2014) Interactions of ion transporters and channels with cancer cell metabolism and the tumour microenvironment. Philos Trans R Soc Lond B Biol Sci 369:20130098

Annis MG, Soucie EL, Dlugosz PJ, Cruz-Aguado JA, Penn LZ, Leber B, Andrews DW (2005) Bax forms multispanning monomers that oligomerize to permeabilize membranes during apoptosis. EMBO J 24:2096-2103

Arcangeli A, Crociani O, Lastraioli E, Masi A, Pillozzi S, Becchetti A (2009) Targeting ion channels in cancer: a novel frontier in antineoplastic therapy. Curr Med Chem 16:66-93

Armstrong CM (2003) Voltage-gated K channels. Sci STKE 2003(188):re10

Arsenijevic D, Onuma H, Pecqueur C, Raimbault S, Manning BS (2000) Disruption of the uncoupling protein-2 gene in mice reveals a role in immunity and reactive oxygen species production. Nat Genet 26:435-439

Artym VV, Petty HR (2002) Molecular proximity of Kv1.3 voltagegated potassium channels and beta(1)-integrins on the plasma membrane of melanoma cells: effects of cell adherence and channel blockers. J Gen Physiol 120:29-37

Ayyasamy V, Owens KM, Desouki MM, Liang P, Bakin A, Thangaraj K, Buchsbaum DJ, LoBuglio AF, Singh KK (2011) Cellular model of Warburg effect identifies tumor promoting function of UCP2 in breast cancer and its suppression by genipin. PLoS ONE 6:e24792

Baffy G (2010) Uncoupling protein-2 and cancer. Mitochondrion $10: 243-252$

Baffy G, Derdak Z, Robson SC (2011) Mitochondrial recoupling: a novel therapeutic strategy for cancer? Br J Cancer 105:469-474

Bai Z, Ye Y, Liang B, Xu F, Zhang H et al (2011) Proteomics-based identification of a group of apoptosis-related proteins and biomarkers in gastric cancer. Int J Oncol 38:375-383

Bai Y et al (2013) MiR-296-3p regulates cell growth and multi-drug resistance of human glioblastoma by targeting ether-a-go-go (EAG1). Eur J Cancer 49:710-724 
Basso K, Margolin AA, Stolovitzky G, Klein U, Dalla-Favera R, Califano A (2005) Reverse engineering of regulatory networks in human B cells. Nat Genet 37:382-390

Bastian A, Thorpe JE, Disch BC, Bailey-Downs LC, Gangjee A, Devambatla RK et al (2015) A small molecule with anticancer and antimetastatic activities induces rapid mitochondrialassociated necrosis in breast cancer. J Pharmacol Exp Ther 353:392-404

Basu Ball W, Kar S, Mukherjee M, Chande AG, Mukhopadhyaya R, Das PK (2011) Uncoupling protein 2 negatively regulates mitochondrial reactive oxygen species generation and induces phosphatase-mediated anti-inflammatory response in experimental visceral leishmaniasis. J Immunol 187:1322-1332

Baughman JM, Perocchi F, Girgis HS, Plovanich M, Belcher-Timme CA, Sancak Y et al (2011) Integrative genomics identifies MCU as an essential component of the mitochondrial calcium uniporter. Nature 476:341-345

Bayliss DA, Barrett PQ (2008) Emerging roles for two-pore-domain potassium channels and their potential therapeutic impact. Trends Pharmacol Sci 29:566-575

Bayliss DA, Sirois JE, Talley EM (2003) The TASK family: two-pore domain background $\mathrm{K}^{+}$channels. Mol Interv 3:205-219

Bednarczyk P, Kowalczyk JE, Beresewicz M, Dolowy K, Szewczyk A, Zablocka B (2010) Identification of a voltage-gated potassium channel in gerbil hippocampal mitochondria. Biochem Biophys Res Commun 397:614-620

Bernardi P, Vassanelli S, Veronese P, Colonna R, Szabo I, Zoratti M (1992) Modulation of the mitochondrial permeability transition pore. Effect of protons and divalent cations. J Biol Chem 267:2934-2939

Bernardi P, Krauskopf A, Basso E, Petronilli V, Blachly-Dyson E, Di Lisa F, Forte MA (2006) The mitochondrial permeability transition from in vitro artifact to disease target. FEBS $\mathrm{J}$ 273:2077-2099

Bernardi P, Forte M (2015) Commentary: SPG7 is an essential and conserved component of themitochondrial permeability transition pore. Front Physiol 6:320. doi:10.3389/ fphys.2015.00320

Bhattacharjee A, Richards WG, Staunton J, Li C, Monti S, Vasa P et al (2001) Classification of human lung carcinomas by mRNA expression profiling reveals distinct adenocarcinoma subclasses. Proc Natl Acad Sci USA 98:13790-13795

Bidaux G, Flourakis M, Thebault S, Zholos A, Beck B, Gkika D et al (2007) Prostate cell differentiation status determines transient receptor potential melastatin member 8 channel subcellular localization and function. J Clin Invest 117:1647-1657

Bielanska J, Hernández-Losa J, Pérez-Verdaguer M, Moline T, Somoza R, Ramón Y et al (2009) Voltage-dependent potassium channels Kv1.3 and Kv1.5 in human cancer. Curr Cancer Drug Targets 9:904-914

Blachly-Dyson E, Forte M (2001) VDAC channels. IUBMB Life 52:113-118

Bomben VC, Sontheimer H (2010) Disruption of transient receptor potential canonical channel 1 causes incomplete cytokinesis and slows the growth of human malignant gliomas. Glia 58:1145-1156

Bomben VC, Turner KL, Barclay TT, Sontheimer H (2011) Transient receptor potential canonical channels are essential for chemotactic migration of human malignant gliomas. J Cell Physiol 226:1879-1888

Brahimi-Horn MC, Ben-Hail D, Ilie M, Gounon P, Rouleau M et al (2012) Expression of a truncated active form of VDAC1 in lung cancer associates with hypoxic cell survival and correlates with progression to chemotherapy resistance. Cancer Res $72: 2140-2150$
Brevet M, Fucks D, Chatelain D, Regimbeau JM, Delcenserie R, Sevestre H, Ouadid-Ahidouch H (2009a) Deregulation of 2 potassium channels in pancreas adenocarcinomas: implication of KV1.3 gene promoter methylation. Pancreas 38:649-654

Brevet M, Haren N, Sevestre H, Merviel P, Ouadid-Ahidouch H (2009b) DNA methylation of KV1.3 potassium channel gene promoter is associated with poorly differentiated breast adenocarcinoma. Cell Physiol Biochem 24:25-32

Cahalan MD, Chandy KG (2009) The functional network of ion channels in T lymphocytes. Immunol Rev 231:59-87

Cairns RA, Harris IS, Mak TW (2011) Regulation of cancer cell metabolism. Nat Rev Cancer 11:85-95

Camello-Almaraz C, Gomez-Pinilla PJ, Pozo MJ, Camello PJ (2006) Mitochondrial reactive oxygen species and $\mathrm{Ca}^{2+}$ signaling. Am J Physiol Cell Physiol 291:C1082-C1088

Carraro M, Giorgio V, Sileikyte J, Sartori G, Forte M, Lippe G, Zoratti M, Szabo I, Bernardi P (2014) Channel Formation by Yeast F-ATP Synthase and the Role of Dimerization in the Mitochondrial Permeability Transition. J Biol Chem 289:15980-15985

Castagna A, Antonioli P, Astner H, Hamdan M, Righetti SC, Perego P, Zunino F, Righetti PG (2004) A proteomic approach to cisplatin resistance in the cervix squamous cell carcinoma cell line A431. Proteomics 4:3246-3267

Cavalieri E, Bergamini C, Mariotto S, Leoni S, Perbellini L, Darra E, Suzuki H, Fato R, Lenaz G (2009) Involvement of mitochondrial permeability transition poreopening in alpha-bisabolol induced apoptosis. FEBS J 276:3990-4000

Chan TO, Tsichlis PN (2001) PDK2: a complex tail in one Akt. Sci STKE. 2001:e1

Checchetto V, Reina S, Magri A, Szabo I, De Pinto V (2014) Recombinant human voltage dependent anion selective channel isoform 3 (hVDAC3) forms pores with a very small conductance. Cell Physiol Biochem 34:842-853

Chen Y, Wei X, Yan P, Han Y, Sun S, Wu K et al (2009) Human mitochondrial Mrs2 protein promotes multidrug resistance in gastric cancer cells by regulating p27, cyclinD1 expression and cytochrome c release. Cancer Biol Ther 8:607-614

Chen Y, Sánchez A, Rubio ME, Kohl T, Pardo LA, Stühmer W (2011) Functional K(v)10.1 channels localize to the inner nuclear membrane. PLoS One 6:e19257

Cheng Y, Gu XQ, Bednarczyk P, Wiedemann FR, Haddad GG, Siemen D (2008) Hypoxia increases activity of the BK-channel in the inner mitochondrial membrane and reduces activity of the permeability transition pore. Cell Physiol Biochem 22:127-136

Cheng Y, Gulbins E, Siemen D (2011) Activation of the permeability transition pore by Bax via inhibition of the mitochondrial BK channel. Cell Physiol Biochem 27:191-200

Cheong A et al (2005) Downregulated REST transcription factor is a switch enabling critical potassium channel expression and cell proliferation. Mol Cell 20:45-52

Chiara F, Rasola A (2013) GSK-3 and mitochondria in cancer cells. Front Oncol 3:16

Chiara F, Castellaro D, Marin O, Petronilli V, Brusilow WS, Juhaszova M, Sollott SJ, Forte M, Bernardi P, Rasola A (2008) Hexokinase II detachment from mitochondria triggers apoptosis through the permeability transition pore independent of voltagedependent anion channels. PLoS One 3:e1852

Chien MM, Zahradka KE, Newell MK, Freed JH (1999) Fas-induced $\mathrm{B}$ cell apoptosis requires an increase in free cytosolic magnesium as a nearly event. J Biol Chem 274:7059-7066

Chodon D, Guilbert A, Dhennin-Duthille I, Gautier M, Telliez MS, Sevestre H, Ouadid-Ahidouch H (2012) Estrogen regulation of TRPM8 expression in breast cancer cells. BMC Cancer 10:212

Cholo MC et al (2012) Clofazimine: current status and future prospects. J Antimicrob Chemother 67:290-298 
Ciscato F, Sciacovelli M, Villano G, Turato C, Bernardi P, Rasola A, Pontisso P (2014) SERPINB3 protects from oxidative damage by chemotherapeutics through inhibition of mitochondrial respiratory complex I. Oncotarget 5:2418-2427

Colombini M, Mannella CA (2012) VDAC, the early days. Biochim Biophys Acta 1818:1438-1443

Comes N, Serrano-Albarrás A, Capera J, Serrano-Novillo C, Condom E, Ramón Y et al (2015) Involvement of potassium channels in the progression of cancer to a more malignant phenotype. Biochim Biophys Acta 1848:2477-2492

Coustan-Smith E, Song G, Clark C, Key L, Liu P, Mehrpooya M et al (2011) New markers for minimal residual disease detection in acute lymphoblastic leukemia. Blood 117:6267-6276

Cui J, Yang H, Lee US (2009) Molecular mechanisms of BK channel activation. Cell Mol Life Sci 66:852-875

Dalla Pozza E, Fiorini C, Dando I, Menegazzi M, Sgarbossa A, Costanzo C, Palmieri M, Donadelli M (2012) Role of mitochondrial uncoupling protein 2 in cancer cell resistance to gemcitabine. Biochim Biophys Acta 1823:1856-1863

Dando I, Fiorini C, Pozza ED, Padroni C, Costanzo C, Palmieri M, Donadelli M (2013) UCP2 inhibition triggers ROS-dependent nuclear translocation of GAPDH and autophagic cell death in pancreatic adenocarcinoma cells. Biochim Biophys Acta 1833:672-679

Davis FM, Parsonage MT, Cabot PJ, Parat MO, Thompson EW, Roberts-Thomson SJ, Monteith GR (2013) Assessment of gene expression of intracellular calcium channels, pumps and exchangers with epidermal growth factor-induced epithelialmesenchymal transition in a breast cancer cell line. Cancer Cell Int 13:76

De Marchi U, Sassi N, Fioretti B, Catacuzzeno L, Cereghetti GM, Szabò I, Zoratti M (2009) Intermediate conductance $\mathrm{Ca}^{2+}$ activated potassium channel (KCa3.1) in the inner mitochondrial membrane of human colon cancer cells. Cell Calcium 45:509-516

De Nicola GM, Karreth FA, Humpton TJ, Gopinathan A, Wei C, Frese $\mathrm{K}$ et al (2011) Oncogene-induced Nrf2 transcription promotes ROS detoxification and tumorigenesis. Nature 475:106-109

De Pinto V, Messina A, Lane DJ, Lawen A (2010) Voltage-dependent anion-selective channel (VDAC) in the plasma membrane. FEBS Lett 584:1793-1799

De Stefani D, Raffaello A, Teardo E, Szabo I, Rizzuto R (2011) A forty-kilodalton protein of the inner membrane is the mitochondrial calcium uniporter. Nature 476:336-340

De Stefani D, Patron M, Rizzuto R (2015) Structure and function of the mitochondrial calcium uniporter complex. Biochim Biophys Acta 1853:2006-2011

Deng YJ, Tang N, Liu C, Zhang JY, An SL, Peng YL, Ma LL, Li GQ, Jiang Q, Hu CT, Wang YN, Liang YZ, Bian XW, Fang WG, Ding YQ (2014) CLIC4, ERp29, and Smac/DIABLO derived from metastatic cancer stem-like cells stratify prognostic risks of colorectal cancer. Clin Cancer Res 20:3809-3817

Deniaud A, Panwar P, Frelet-Barrand A, Bernaudat F, Juillan-Binard C, Ebel C, Rolland N, Pebay-Peyroula E (2012) Oligomeric status and nucleotide binding properties of the plastid ATP/ADP transporter 1: toward a molecular understanding of the transport mechanism. PLoS One 7:e32325

Denton RM (2009) Regulation of mitochondrial dehydrogenases by calcium ions. Biochim Biophys Acta 1787:1309-1316

Denton RM, McCormack JG (1980) On the role of the calcium transport cycle in heart and other mammalian mitochondria. FEBS Lett 119:1-8

Denton RM, Randle PJ, Martin BR (1972) Stimulation by calcium ions of pyruvate dehydrogenase phosphate phosphatase. Biochem J 128:161-163
Denton RM, Richards DA, Chin JG (1978) Calcium ions and the regulation of NAD+ -linked isocitrate dehydrogenase from the mitochondria of rat heart and other tissues. Biochem J 176:899-906

Denton RM, McCormack JG, Edgell NJ (1980) Role of calcium ions in the regulation of intramitochondrial metabolism. Effects of $\mathrm{Na}^{+}, \mathrm{Mg}^{2+}$ and ruthenium red on the $\mathrm{Ca}^{2+}$-stimulated oxidation of oxoglutarate and on pyruvate dehydrogenase activity in intact rat heart mitochondria. Biochem J 190:107-117

Derdak Z, Mark NM, Beldi G, Robson SC, Wands JR, Baffy G (2008) The mitochondrial uncoupling protein-2 promotes chemoresistance in cancer cells. Cancer Res 68:2813-2819

Detwiller KY, Fernando NT, Segal NH, Ryeom SW, D'Amore PA, Yoon SS (2005) Analysis of hypoxia-related gene expression in sarcomas and effect of hypoxiaon RNA interference of vascular endothelial cell growth factor A. Cancer Res 65:5881-5889

Dhennin-Duthille I, Gautier M, Faouzi M, Guilbert A, Brevet M, Vaudry D, Ahidouch A, Sevestre H, Ouadid-Ahidouch H (2011) High expression of transient receptor potential channels in human breast cancer epithelial cells and tissues: Correlation with pathological parameters. Cell Physiol Biochem 28:813-822

Dhillon AS, Hagan S, Rath O, Kolch W (2007) MAP kinase signalling pathways in cancer. Oncogene 26:3279-3290

Djamgoz MB, Onkal R (2013) Persistent current blockers of voltagegated sodium channels: a clinical opportunity for controlling metastatic disease. Recent Pat Anticancer Drug Discov 8:66-84

Douglas RM, Lai JC, Bian S, Cummins L, Moczydlowski E, Haddad GG (2006) The calcium sensitive large-conductance potassium channel (BK/MAXI K) is present in the inner mitochondrial membrane of rat brain. Neuroscience 139:1249-1261

Downie BR et al (2008) Eag1 expression interferes with hypoxia homeostasis and induces angiogenesis in tumors. J Biol Chem 283:36234-36240

Downward J (2003) Targeting RAS signalling pathways in cancer therapy. Nat Rev Cancer 3:11-22

Drago I, De Stefani D, Rizzuto R, Pozzan T (2012) Mitochondrial $\mathrm{Ca}^{2+}$ uptake contributes to buffering cytoplasmic $\mathrm{Ca}^{2+}$ peaks in cardiomyocytes. Proc Natl Acad Sci USA 109:12986-12991

Du GJ, Li JH, Liu WJ, Liu YH, Zhao B, Li HR, Hou XD, Li H, Qi XX, Duan YJ et al (2014) The combination of TRPM8 and TRPA1 expression causes an invasive phenotype in lung cancer. Tumor Biol 35:1251-1261

Duchen MR (1992) Ca(2+)-dependent changes in the mitochondrial energetics in single dissociated mouse sensory neurons. Biochem J 283:41-50

Duchen MR (2000) Mitochondria and calcium: from cell signalling to cell death. J Physiol 529:57-68

Dyrskjøt L, Kruhøffer M, Thykjaer T, Marcussen N, Jensen JL, Møller K, Ørntoft TF (2004) Gene expression in the urinary bladder: a common carcinoma in situ gene expression signature exists disregarding histopathological classification. Cancer Res 64:4040-4048

Eckenrode EF, Yang J, Velmurugan GV, Foskett JK, White C (2010) Apoptosis protection by Mcl-1 and Bcl-2 modulation of inositol 1,4,5-trisphosphate receptor-dependent $\mathrm{Ca}^{2+}$ signaling. J Biol Chem 285:13678-13684

Eichhorn B, Dobrev D (2007) Vascular large conductance calciumactivated potassium channels: functional role and therapeutic potential. Naunyn Schmiedebergs Arch Pharmacol 376:145-155

Ekhterae D, Platoshyn O, Zhang S, Remillard CV, Yuan JX (2003) Apoptosis repressor with caspase domain inhibits cardiomyocyte apoptosis by reducing $\mathrm{K}^{+}$currents. Am J Physiol Cell Physiol 284:C1405-C1410

Félétou M (2009) Calcium-activated potassium channels and endothelial dysfunction: therapeutic options? Br J Pharmacol $156: 545-562$ 
Felipe A, Vicente R, Villalonga N, Roura-Ferrer M, Martinez-Marmol R, Sole L, Ferreres JC, Condom E (2006) Potassium channels: new targets in cancer therapy. Cancer Detect Prev 30:375-385

Fernández-Salas E, Sagar M, Cheng C, Yuspa SH, Weinberg WC (1999) p53 and tumor necrosis factor alpha regulate the expression of a mitochondrial chloride channel protein. J Biol Chem 274:36488-36497

Fernández-Salas E, Suh KS, Speransky VV, Bowers WL, Levy JM, Adams T et al (2002) mtCLIC/CLIC4, an organellular chloride channel protein, is increased by DNA damage and participates in the apoptotic response to p53. Mol Cell Biol 22:3610-3620

Finak G, Bertos N, Pepin F, Sadekova S, Souleimanova M, Zhao H et al (2008) Stromal gene expression predicts clinical outcome in breast cancer. Nat Med 14:518-527

Fiorini C, Cordani M, Gotte G, Picone D, Donadelli M (2015) Onconase induces autophagy sensitizing pancreatic cancer cells to gemcitabine and activates Akt/mTOR pathway in a ROSdependent manner. Biochim Biophys Acta 1853:549-560

Foskett JK, Philipson B (2015) The mitochondrial $\mathrm{Ca}(2+)$ uniporter complex. J Mol Cell Cardiol 78:3-8

Fujimoto T, Machida T, Tsunoda T, Doi K, Ota T, Kuroki M et al (2011) KRAS induced actin-interacting protein regulates inositol 1,4,5-trisphosphatereceptor- mediated calcium release. Biochem Biophys Res Commun 408:214-217

Gabriel Pons D, Nadal-Serrano M, Torrens-Mas M, Valle A, Oliver J, Roca P (2015) UCP2 inhibition sensitizes breast cancer cells to therapeutic agents by increasing oxidative stress. Free Radic Biol Med 86:67-77

Gaikwad A, Poblenz A, Haridas V, Zhang C, Duvic M, Gutterman J (2005) Triterpenoid electrophiles (avicins) suppress heat shock protein-70 and x-linked inhibitor of apoptosis proteins in malignant cells by activation of ubiquitin machinery: implications for proapoptotic activity. Clin Cancer Res 11:1953-1962

Ghosh T, Pandey N, Maitra A, Brahmachari SK, Pillai B (2007) A role for voltage dependent anion channel Vdac1 in polyglutamine-mediated neuronal cell death. PLoS One 2:e1170

Ghosh JC, Siegelin MD, Dohi T, Altieri DC (2010) Heat shock protein 60 regulation of the mitochondrial permeability transition pore in tumor cells. Cancer Res 70:8988-8993

Giardina TM, Steer JH, Lo SZ, Joyce DA (2008) Uncoupling protein-2 accumulates rapidly in the inner mitochondrial membrane during mitochondrial reactive oxygen stress in macrophages. Biochim Biophys Acta 1777:118-129

Giorgio V, von Stockum S, Antoniel M, Fabbro A, Fogolari F, Forte M, Glick GD, Petronilli V, Zoratti M, Szabo I, Lippe G, Bernardi P (2013) Dimers of mitochondrial ATP synthase form the permeability transition pore. Proc Natl Acad Sci USA 110:5887-5892

Gkika D, Lemonnier L, Shapovalov G, Gordienko D, Poux C, Bernardini M, Bokhobza A, Bidaux G, Degerny C, Verreman K, Guarmit B, Benahmed M, de Launoit Y, Bindels RJ, Fiorio Pla A, Prevarskaya N (2015) TRP channel-associated factors are a novel protein family that regulates TRPM8 trafficking and activity. J Cell Biol 208:89-107

Godbole A, Varghese J, Sarin A, Mathew MK (2003) VDAC is a conserved element of death pathways in plant and animal systems. Biochim Biophys Acta 1642:87-96

Gordon GJ, Rockwell GN, Jensen RV, Rheinwald JG, Glickman JN, Aronson JP et al (2005) Identification of novel candidate oncogenes and tumor suppressors in malignant pleural mesothelioma using large-scale transcriptional profiling. Am J Pathol 166:1827-1840

Gorrini C, Harris IS, Mak TW (2013) Modulation of oxidative stress as an anti cancer strategy. Nat Rev Drug Discov 12:931-947

Grek CL, Tew KD (2010) Redox metabolism and malignancy. Curr Opin Pharmacol 10:362-368
Grills C, Jithesh PV, Blayney J, Zhang SD, Fennell DA (2011) Gene expression meta-analysis identifies VDAC1 as a predictor of poor outcome in early stage non-small cell lung cancer. PLoS One 6:e14635

Gu XQ, Siemen D, Parvez S, Cheng Y, Xue J, Zhou D, Sun X, Jonas EA, Haddad GG (2007) Hypoxia increases BK channel activity in the inner mitochondrial membrane. Biochem Biophys Res Commun 358:311-316

Gulbins E, Sassi N, Grassme H, Zoratti M, Szabò I (2010) Role of Kv1.3 mitochondrial potassium channel in apoptotic signalling in lymphocytes. Biochim Biophys Acta 1797:1251-1259

Gutman GA, Chandy KG, Adelman JP, Aiyar J, Bayliss DA, Clapham DE, Covarriubias $M$ et al (2003) International Union of Pharmacology. XLI. Compendium of voltage-gated ion channels: potassium channels. Pharmacol Rev 55:583-586

Gutman GA, Chandy KG, Grissmer S, Lazdunski M, McKinnon D, Pardo LA et al (2005) International Union of Pharmacology. LIII. Nomenclature and molecular relationships of voltagegated potassium channels. Pharmacol Rev 57:473-508

Haferlach T, Kohlmann A, Wieczorek L, Basso G, Kronnie GT, Béné MC et al (2010) Clinical utility of microarray-based gene expression profiling in the diagnosis and subclassification of leukemia: report from the International Microarray Innovations in Leukemia Study Group. J Clin Oncol 28:2529-2537

Hall DD, Wu Y, Domann FE, Spitz DR, Anderson ME (2014) Mitochondrial calcium uniporter activity is dispensable for MDAMB-231 breast carcinoma cell survival. PLoS ONE 9:e96866

Hammadi $\mathrm{M}$ et al (2012) Human ether a-gogo $\mathrm{K}^{+}$channel 1 (hEag1) regulates MDA-MB-231 breast cancer cell migration through Orai1-dependent calcium entry. J Cell Physiol 227:3837-3846

Han W, Li L, Qiu S, Lu Q, Pan Q, Gu Y, Luo J, Hu X (2007) Shikonin circumventscancer drug resistance by induction of a necroptotic death. Mol Cancer Ther 6:1641-1649

Hanahan D, Weinberg RA (2000) The hallmarks of cancer. Cell 100:57-70

Hanahan D, Weinberg RA (2011) Hallmarks of cancer: the next generation. Cell 144:646-674

Hao Y, Triadafilopoulos G, Sahbaie P, Young HS, Omary MB, Lowe AW (2006) Gene expression profiling reveals stromal genes expressed in common between Barrett's esophagus and adenocarcinoma. Gastroenterology 131:925-933

Haridas V, Kim SO, Nishimura G, Hausladen A, Stamler JS, Gutterman JU (2005) Avicinylation (thioesterification): a protein modification that can regulate the response to oxidative and nitrosative stress. Proc Natl Acad Sci USA 102:10088-10093

He B, Liu F, Ruan J, Li A, Chen J et al (2012) Silencing TRPC1 expression inhibits invasion of CNE2 nasopharyngeal tumor cells. Oncol Rep 27:1548-1554

Hegle AP, Marble DD, Wilson GF (2006) A voltage driven switch for ion-independent signaling by ether-à go-go $\mathrm{K}^{+}$channels. Proc Natl Acad Sci USA 103:2886-2891

Heinen A, Aldakkak M, Stowe DF, Rhodes SS, Riess ML, Varadarajan SG, Camara AK (2007a) Reverse electron flow induced ROS production is attenuated by activation of mitochondrial $\mathrm{Ca}^{2+}$-sensitive $\mathrm{K}^{+}$channels. Am J Physiol Heart Circ Physiol 293:H1400-H1407

Heinen A, Camara AK, Aldakkak M, Rhodes SS, Riess ML, Stowe DF (2007b) Mitochondrial $\mathrm{Ca}^{2+}$-induced $\mathrm{K}^{+}$influx increases respiration and enhances ROS production while maintaining membrane potential. Am J Physiol Cell Physiol 292:C148-C156

Herrmann S, Ninkovic M, Kohl T, Lörinczi E, Pardo LA (2012) Cortactin controls surface expression of the voltage-gated potassium channel KV10.1. J Biol Chem 287:44151-44163

Hoffmann EK, Lambert IH (2014) Ion channels and transporters in the development of drug resistance in cancer cells. Philos Trans R Soc Lond B Biol Sci 369:20130109 
Holness MJ, Sugden MC (2003) Regulation of pyruvate dehydrogenase complex activity by reversible phosphorylation. Biochem Soc Trans 31:1143-1151

Hoshi M, Takashima A, Noguchi K, Murayama M, Sato M, Kondo S et al (1996) Regulation of mitochondrial pyruvate dehydrogenase activity by tau protein kinase I/glycogen synthase kinase3beta in brain. Proc Natl Acad Sci USA 93:2719-2723

Huang G, Vercesi AE, Docampo R (2013) Essential regulation of cell bioenergetics in Trypanosoma brucei by the mitochondrial calcium uniporter. Nat Commun 4:2865

Iacobuzio-Donahue CA, Maitra A, Olsen M, Lowe AW, van Heek NT, Rosty C et al (2003) Exploration of global gene expression patterns in pancreatic adenocarcinoma using cDNA microarrays. Am J Pathol 162:1151-1162

Innamaa A, Jackson L, Asher V, Van Shalkwyk G, Warren A, Hay D et al (2013) Expression and prognostic significance of the oncogenic K2P potassium channel KCNK9 (TASK-3) in ovarian carcinoma. Anticancer Res 33:1401-1408

Jang SH, Kang KS, Ryu PD, Lee SY (2009) Kv1.3 voltage-gated $\mathrm{K}^{+}$channel subunit as a potential diagnostic marker and therapeutic target for breast cancer. BMB Rep 42:535-539

Jang SH, Byun JK, Jeon WI, Choi SY, Park J, Lee BH, Yang JE, Park JB, O’Grady SM, Kim DY, Ryu PD, Joo SW, Lee SY (2015) Nuclear localization and functional characteristics of voltagegated potassium channel Kv1.3. J Biol Chem 290:12547-12557

Jones J, Otu H, Spentzos D, Kolia S, Inan M, Beecken WD et al (2005) Gene signatures of progression and metastasis in renal cell cancer. Clin Cancer Res 11:5730-5739

Jope RS, Johnson GV (2004) The glamour and gloom of glycogen synthase kinase-3. Trends Biochem Sci 29:95-102

Jope RS, Yuskaitis CJ, Beurel E (2007) Glycogen synthase kinase-3 (GSK3): inflammation, diseases, and therapeutics. Neurochem Res 32:577-595

Juhaszova M, Zorov DB, Yaniv Y, Nuss HB, Wang S, Sollott SJ (2009) Role ofglycogen synthase kinase-3beta in cardioprotection. Circ Res 104:1240-1252

Kang BH, Plescia J, Dohi T, Rosa J, Doxsey SJ, Altieri DC (2007) Regulation oftumor cell mitochondrial homeostasis by an organelle-specific Hsp90 chaperone network. Cell 131:257-270

Kang SS, Han KS, Ku BM, Lee YK, Hong J, Shin HY et al (2010) Caffeine-mediated inhibition of calcium release channel inositol 1,4,5-trisphosphate receptor subtype 3 blocks glioblastoma invasion and extends survival. Cancer Res 70:1173-1183

Kathiresan T, Harvey M, Orchard S, Sakai Y, Sokolowski B (2009) A protein interaction network for the large conductance $\mathrm{Ca}^{2+}$. activated $\mathrm{K}^{+}$channel in the mouse cochlea. Mol Cell Proteomics 8:1972-1987

Khan MB, Sjöblom B, Schweyen RJ, Djinovi'c-Carugo K (2010) Crystallization and preliminary $\mathrm{X}$-ray diffraction analysis of theNH2-terminal domain of Mrs2, a magnesium ion transporter from yeast inner mitochondrial membrane. Acta Crystallogr, Sect F: Struct Biol Cryst Commun 66:658-661

Kim TH, Zhao Y, Barber MJ, Kuharsky DK, Yin XM (2000) Bidinduced cytochrome $\mathrm{c}$ release is mediated by a pathway independent of mitochondrial permeability transition pore and Bax. J Biol Chem 275:39474-39481

Kim CJ, Cho YG, Jeong SW, Kim YS, Kim SY, Nam SW, Lee SH, Yoo NJ, Lee JY, Park WS (2004) Altered expression of KCNK9 in colorectal cancers. APMIS 112:588-594

King TD, Clodfelder-Miller B, Barksdale KA, Bijur GN (2008) Unregulated mitochondrial GSK3beta activity results in NADH: ubiquinone oxidoreductase deficiency. Neurotox Res 14:367-382

Kinnally KW, Campo ML, Tedeschi H (1989) Mitochondrial channel activity stud-ied by patch-clamping mitoplasts. J Bioenerg Biomembr 21:497-506
Kirichok Y, Krapivinsky G, Clapham DE (2004) The mitochondrial calcium uniporter is a highly selective ion channel. Nature 427:360-364

Klohn PC, Soriano ME, Irwin W, Penzo D, Scorrano L, Bitsch A, Neumann HG, Bernardi P (2003) Early resistance to cell death and to onset of the mitochondrial permeability transition during hepatocarcinogenesis with 2-acetylaminofluorene. Proc Natl Acad Sci USA 100:10014-10019

Kohl T, Lörinczi E, Pardo LA, Stühmer W (2011) Rapid internalization of the oncogenic $\mathrm{K}^{+}$channel $\mathrm{K}(\mathrm{V}) 10.1$. PLoS One 6:e26329

Kolisek M, Zsurka G, Samaj J, Weghuber J, Schweyen RJ, Schweigel M (2003) Mrs2p is an essential component of the major electrophoretic $\mathrm{Mg}^{2+}$ influx system in mitochondria. EMBO J 22:1235-1244

Korkola JE, Houldsworth J, Chadalavada RS, Olshen AB, Dobrzynski D, Reuter VE, Bosl GJ, Chaganti RS (2006) Down-regulation of stem cell genes, including those in a 200-kb gene cluster at $12 \mathrm{p} 13.31$, is associated with in vivo differentiation of human male germ cell tumors. Cancer Res 66:820-827

Kosztka L, Rusznák Z, Nagy D, Nagy Z, Fodor J, Szucs G et al (2011) Inhibition of TASK-3 (KCNK9) channel biosynthesis changes cell morphology and decreases both DNA content and mitochondrial function of melanoma cells maintained in cell culture. Melanoma Res 21:308-322

Kovacs I, Pocsai K, Czifra G, Sarkadi L, Szucs G, Nemes Z, Rusznak Z (2005) TASK-3 immunoreactivity shows differential distribution in the human gastrointestinal tract. Virchows Arch 446:402-410

Krauss S, Zhang CY, Lowell BB (2005) The mitochondrial uncoupling-protein homologues. Nat Rev Mol Cell Biol 6:248-261

Kubota T, Shindo Y, Tokuno K, Komatsu H, Ogawa H, Kudo S, Kitamura Y, Suzuki K, Oka K (2005) Mitochondria are intracellular magnesium stores: investigation by simultaneous fluorescent imagings in PC12 cells. Biochim Biophys Acta 1744:19-28

Lai JC, Tan W, Benimetskaya L, Miller P, Colombini M, Stein CA (2006) A pharmacologic target of G3139 in melanoma cells may be the mitochondrial VDAC. Proc Natl Acad Sci USA 103:7494-7499

Lan M, Shi Y, Han Z, Hao Z, Pan Y, Liu N, Guo C, Hong L, Wang J, Qiao T, Fan D (2005) Expression of delayed rectifier potassium channels and their possible roles in proliferation of human gastric cancer cells. Cancer Biol Ther 4:1342-1347

Leanza L, Henry B, Sassi N, Zoratti M, Chandy KG, Gulbins E, Szabò I (2012a) Inhibitors of mitochondrial Kv1.3 channels induce Bax/Bak-independent death of cancer cells. EMBO Mol Med 4:577-593

Leanza L, Zoratti M, Gulbins E, Szabò I (2012b) Induction of apoptosis in macrophages via Kv1.3 and Kv1.5 potassium channels. Curr Med Chem 19:5394-5404

Leanza L, Biasutto L, Manago A, Gulbins E, Zoratti M, Szabò I (2013a) Intracellular ion channels and cancer. Front Physiol 4:227

Leanza L, Trentin L, Becker KA, Frezzato F, Zoratti M, Semenzato G, Gulbins E, Szabò I (2013b) Clofazimine, Psora-4 PAP-1, inhibitors of the potassium channel Kv1.3, as a new and selective therapeutic strategy in chronic lymphocytic leukemia. Leukemia 27:1782-1785

Leanza L, O'Reilly P, Doyle A, Venturini E, Zoratti M, Szegezdi E, Szabo I (2014a) Correlation between potassium channel expression and sensitivity to drug-induced cell death in tumor cell lines. Curr Pharm Des 20:189-200

Leanza L, Zoratti M, Gulbins E, Szabo I (2014b) Mitochondrial ion channels as oncological targets. Oncogene 33:5569-5581

Leanza L, Managò A, Zoratti M, Gulbins E, Szabo I (2015a) Pharmacological targeting of ion channels for 
cancer therapy: in vivo evidences. Biochim Biophys Acta pii S0167-4889(15):00416-00417

Leanza L, Venturini E, Kadow S, Carpinteiro A, Gulbins E, Becker KA (2015b) Targeting a mitochondrial potassium channel to fight cancer. Cell Calcium 58:131-138

Lee JM, Davis FM, Roberts-Thomson SJ, Monteith GR (2011) Ion channels and transporters in cancer. 4. Remodeling of $\mathrm{Ca}(2+)$ signaling in tumorigenesis: role of $\mathrm{Ca}(2+)$ transport. Am J Physiol Cell Physiol 301:C969-C976

Lee GW, Park HS, Kim EJ, Cho YW, Kim GT, Mun YJ et al (2012) Reduction of breast cancer cell migration via up-regulation of TASK-3 two-pore domain $\mathrm{K}^{+}$channel. Acta Physiol 204:513-524

Lee Y, Min CK, Kim TG, Song HK, Lim Y, Kim D et al (2015) Structure and function of the N-terminal domain of the human mitochondrial calcium uniporter. EMBO Rep 16:1318-1333

Lena A, Rechichi M, Salvetti A, Bartoli B, Vecchio D, Scarcelli V et al (2009) Drugs targeting the mitochondrial pore act as cytotoxic and cytostatic agents in temozolomide-resistantglioma cells. J Transl Med 7:13

Letai AG (2008) Diagnosing and exploiting cancer's addiction to blocks in apoptosis. Nat Rev Cancer 8:121-132

Li C, Wang X, Vais H, Thompson CB, Foskett JK, White C (2007a) Apoptosis regulation by $\mathrm{Bcl}-\mathrm{x}(\mathrm{L})$ modulation of mammalian inositol 1,4,5-trisphosphate receptor channel isoform gating. Proc Natl Acad Sci USA 104:12565-12570

Li L, Han W, Gu Y, Qiu S, Lu Q, Jin J, Luo J, Hu X (2007b) Honokiol induces a necrotic cell death through the mitochondrial permeability transition pore. Cancer Res 67:4894-4903

Lim HY, Yip YM, Chiong E, Tiong HY, Halliwell B, Esuvaranathan K, Wong KP (2015) Metabolic signatures of renal cell carcinoma. Biochem Biophys Res Commun 460:938-943

Lin $\mathrm{H}$ et al (2011) Transcriptional and posttranscriptional mechanisms for oncogenic overexpression of ether à go-go $\mathrm{K}^{+}$channel. PLoS One 6:e20362

Litan A, Langhans SA (2015) Cancer as a channelopathy: ion channels and pumps in tumor development and progression. Front Cell Neurosci 9:86

Liu J, Chen Y, Shuai S, Ding D, Li R, Luo R (2014) TRPM8 promotes aggressiveness of breast cancer cells by regulating EMT via activating AKT/GSK-3 pathway. Tumor Biol 35:8969-8977

Logan CV, Szabadkai G, Sharpe JA, Parry DA, Torelli S, Childs AM et al (2014) Loss-of-function mutations in MICU1 cause a brain and muscle disorder linked to primary alterations in mitochondrial calcium signaling. Nat Genet 46:188-193

Lu AJ, Dong CW, Du CS, Zhang QY (2007) Characterization and expression analysis of Paralichthys olivaceus voltage-dependent anion channel (VDAC) gene in response to virus infection. Fish Shellfish Immunol 23:601-613

Ma X, Tian X, Huang X, Yan F, Qiao D (2007) Resveratrol-induced mitochondrial dysfunction and apoptosis are associated with $\mathrm{Ca}^{2+}$ and mCICR-mediated MPT activation in HepG2 cells. Mol Cell Biochem 302:99-109

Ma XJ, Dahiya S, Richardson E, Erlander M, Sgroi DC (2009) Gene expression profiling of the tumor microenvironment during breast cancer progression. Breast Cancer Res 11:R7

MacKinnon R (2003) Potassium channels. FEBS Lett 555:62-65

Mahamdallie SS, Hanks S, Karlin KL, Zachariou A, Perdeaux ER, Ruark E et al (2015) Mutations in the transcriptional repressor REST predispose to Wilms tumor. Nat Genet 47:1471-1474

Mallilankaraman K, Doonan P, Cardenas C, Chandramoorthy HC, Muller M, Miller R et al (2012) MICU1 is an essential gatekeeper for MCU-mediated mitochondrial $\mathrm{Ca}(2+)$ uptake that regulates cell survival. Cell 151:630-644
Mammucari C, Gherardi G, Zamparo I, Raffaello A, Boncompagni S, Chemello F et al (2015) The mitochondrial calcium uniporter controls skeletal muscle trophism in vivo. Cell Rep 10:1269-1279

Martínez R, Stühmer W, Martin S, Schell J, Reichmann A, Rohde V, Pardo L (2015) Analysis of the expression of Kv10.1 potassium channel in patients with brain metastases and glioblastoma multiforme: impact on survival. BMC Cancer 15:839

McCormack JG, Denton RM (1979) The effects of calcium ions and adenine nucleotides on the activity of pig heart 2-oxoglutarate dehydrogenase complex. Biochem J 180:533-544

McCormack JG, Halestrap AP, Denton RM (1990) Role of calcium ions in regulation of mammalian intramitochondrial metabolism. Physiol Rev 70:391-425

McFerrin MB, Turner KL, Cuddapah VA, Sontheimer H (2012) Differential role of IK and BK potassium channels as mediators of intrinsic and extrinsic apoptotic cell death. Am J Physiol Cell Physiol 303:C1070-C1078

Messina A, Reina S, Guarino F, De Pinto V (2012) VDAC isoforms in mammals. Biochim Biophys Acta 1818:1466-1476

Miura T, Miki T (2009) GSK-3beta, a therapeutic target for cardiomyocyte protection. Circ J 73:1184-1192

Monaco G, Decrock E, Arbel N, van Vliet AR, La Rovere RM, De Smedt $\mathrm{H}$ et al (2015) The BH4 domain of anti-apoptotic Bcl$\mathrm{XL}$, but not that of the related $\mathrm{Bcl}-2$, limits the voltage-dependent anion channel 1 (VDAC1)-mediated transfer of pro-apoptotic $\mathrm{Ca}^{2+}$ signals to mitochondria. J Biol Chem 290:9150-9161

Monteith GR, Davis FM, Roberts-Thomson SJ (2012) Calcium channels and pumps in cancer: changes and consequences. J Biol Chem 287:31666-31673

Mound A, Rodat-Despoix L, Bougarn S, Ouadid-Ahidouch H, Matifat F (2013) Molecular interaction and functional coupling between type 3 inositol 1,4,5-trisphosphate receptor and BKCa channel stimulate breast cancer cell proliferation. Eur J Cancer 49:3738-3751

Mu D, Chen L, Zhang X, See LH, Koch CM, Yen C et al (2003) Genomic amplification and oncogenic properties of the KCNK9 potassium channel gene. Cancer Cell 3:297-302

Munaron L (2015) Systems biology of ion channels and transporters in tumor angiogenesis: An omics view. Biochim Biophys Acta 1848(10 Pt B):2647-56

Naghdi S, Hajnóczky G (2016) VDAC2-specific cellular functions and the underlying structure. Biochim Biophys Acta pii:S0167-4889(16)30120-3

Nagy D, Gönczi M, Dienes B, Szöőr Á, Fodor J, Nagy Z, Tóth A, Fodor T, Bai P, Szücs G, Rusznák Z, Csernoch L (2014) Silencing the KCNK9 potassium channel (TASK-3) gene disturbs mitochondrial function, causes mitochondrial depolarization, and induces apoptosis of human melanoma cells. Arch Dermatol Res 306:885-902

Nilius B (2007) TRP channels in disease Biochim. Biophy. Acta 1772:805-812

Nilius B, Owsianik G (2011) The transient receptor potential family of ion channels Genome Biol. 12:218

Nilius B, Owsianik G, Voets T, Peters JA (2007) Transient receptor potential cation channels in disease. Physiol Rev 87:165-217

Nindl I, Dang C, Forschner T, Kuban RJ, Meyer T, Sterry W, Stockfleth E (2006) Identification of differentially expressed genes in cutaneous squamous cell carcinoma by microarray expression profiling. Mol Cancer 5:30

Ninkovic M, Mitkovski M, Kohl T, Stühmer W, Pardo LA (2012) Physical and functional interaction of KV10.1 with Rabaptin-5 impacts ion channel trafficking. FEBS Lett 586:3077-3084

Noriega-Navarro R, Lopez-Charcas O, Hernández-Enríquez B, Reyes-Gutiérrez PE, Martínez R, Landa A, Morán J, Gomora JC, Garcia-Valdes J (2014) Novel TASK channels inhibitors 
derived from dihydropyrrolo[2,1- $\alpha]$ isoquineolin. Neuropharmacology 79:28-36

Norman KG, Canter JA, Shi M, Milne GL, Morrow JD, Sligh JE (2010) Cyclosporine A suppresses keratinocyte cell death through MPTP inhibition in a model for skin cancer in organ transplant recipients. Mitochondrion 10:94-101

O'Grady SM, Lee SY (2005) Molecular diversity and function of voltage-gated (Kv)potassium channels in epithelial cells. Int $\mathbf{J}$ Biochem Cell Biol 37:1578-1594

O'Rourke B (2007) Mitochondrial ion channels. Annu Rev Physiol 69:19-49

Oakes SA, Scorrano L, Opferman JT, Bassik MC, Nishino M, Pozzan $\mathrm{T}$ et al (2005) Proapoptotic BAX and BAK regulate the type 1 inositol trisphosphate receptor and calcium leak from the endoplasmic reticulum. Proc Natl Acad Sci USA 102:105-110

Ohya S, Kuwata Y, Sakamoto K, Muraki K, Imaizumi Y (2005) Cardioprotective effects of estradiol include the activation of largeconductance $\mathrm{Ca}^{2+}$-activated $\mathrm{K}^{+}$channels in cardiac mitochondria. Am J Physiol Heart Circ Physiol 289:H1635-H1642

Okudela K, Katayama A, Woo T, Mitsui H, Suzuki T et al (2014) Proteome analysis for downstream targets of oncogenic KRASthe potential participation of clic4 in carcinogenesis in the lung. PLoS One 9:e87193

Pagliarini DJ, Calvo SE, Chang B, Sheth SA, Vafai SB, Ong SE et al (2008) A mitochondrial protein compendium elucidates complex I disease biology. Cell 134:112-123

Pan X, Liu J, Nguyen T, Liu C, Sun J, Teng Y et al (2013) The physiological role of mitochondrial calcium revealed by mice lacking the mitochondrial calcium uniporter. Nat Cell Biol 15:1464-1472

Pardo LA, Stühmer W (2014) The roles of $\mathrm{K}^{+}$channels in cancer. Nature Rev Cancer 14:39-48

Pardo LA et al (1999) Oncogenic potential of EAG $\mathrm{K}^{+}$channels. EMBO J 18:5540-5547

Patel AJ, Lazdunski M (2004) The 2P-domain $\mathrm{K}^{+}$channels: role in apoptosis and tumorigenesis. Pflugers Arch 448:261-273

Patra KC, Wang Q, Bhaskar PT, Miller L, Wang Z, Wheaton W, Chandel $\mathrm{N}$ et al (2013) Hexokinase 2 is required for tumor initiation and maintenance and its systemic deletion is therapeutic in mouse models of cancer. Cancer Cell 24:213-228

Pei H, Li L, Fridley BL, Jenkins GD, Kalari KR, Lingle W et al (2009) FKBP51 affects cancer cell response to chemotherapy by negatively regulating Akt. Cancer Cell 16:259-266

Pendin D, Greotti E, Pozzan T (2014) The elusive importance of being a mitochondrial $\mathrm{Ca}(2+)$ uniporter. Cell Calcium 55:139-145

Peretti M, Angelini M, Savalli N, Florio T, Yuspa SH, Mazzanti M (2015) Chloride channels in cancer: focus on chloride intracellular channel 1 and 4 (CLIC1 AND CLIC4) proteins in tumor development and as novel therapeutic targets. Biochim Biophys Acta 1848:2523-2531

Pernemalm M, De Petris L, Branca RM, Forshed J, Kanter L, Soria JC et al (2013) Quantitative proteomics profiling of primary lung adenocarcinoma tumors reveals functional perturbations in tumor metabolism. J Proteome Res 12:3934-3943

Petronilli V, Szabo I, Zoratti M (1989) The inner mitochondrial membrane contains ion-conducting channels similar to those found in bacteria. FEBS Lett 259:137-143

Piccaluga PP, Agostinelli C, Califano A, Rossi M, Basso K, Zupo S et al (2007) Gene expression analysis of peripheral T cell lymphoma, unspecified, reveals distinct profiles and new potential therapeutic targets. J Clin Invest 117:823-834

Pierro C, Cook SJ, Foets TC, Bootman MD, Roderick HL (2014) Oncogenic K-Ras suppresses $\mathrm{IP}_{3}$-dependent $\mathrm{Ca}^{2+}$ release through remodelling of the isoform composition of $\mathrm{IP}_{3} \mathrm{Rs}$ and ER luminal $\mathrm{Ca}^{2+}$ levels in colorectal cancer cell lines. J Cell Sci 127:1607-1619
Piskacek M, Zotova L, Zsurka G, Schweyen RJ (2009) Conditional knockdown of hMRS2 results in loss of mitochondrial $\mathrm{Mg}(2+)$ uptake and cell death. J Cell Mol Med 13:693-700

Piwonska M, Wilczek E, Szewczyk A, Wilczynski GM (2008) Differential distribution of $\mathrm{Ca}^{2+}$-activated potassium channel beta4 subunit in rat brain: immunolocalization in neuronal mitochondria. Neuroscience 153:446-460

Pocsai K, Kosztka L, Bakondi G, Gonczi M, Fodor J, Dienes B et al (2006) Melanoma cells exhibit strong intracellular TASK3 -specific immunopositivity in both tissue sections and cell culture. Cell Mol Life Sci 63:2364-2376

Pomeroy SL, Tamayo P, Gaasenbeek M, Sturla LM, Angelo M, McLaughlin ME et al (2002) Prediction of central nervous system embryonal tumour outcome based on gene expression. Nature 415:436-442

Pralong WF, Hunyady L, Varnai P, Wollheim CB, Spat A (1992) Pyridine nucleotide redox state parallels production of aldosterone in potassium-stimulated adrenal glomerulosa cells. Proc Natl Acad Sci USA 89:132-136

Preussat K, Beetz C, Schrey M, Kraft R, Wolfl S, Kalff R, Patt S (2003) Expression of voltage-gated potassium channels Kv1.3 and Kv1.5 in human gliomas. Neurosci Lett 346:33-36

Prevarskaya N, Skryma R, Shuba Y (2011) Calcium in tumour metastasis: new roles for known actors. Nat Rev Cancer 11:609-618

Pro B, Leber B, Smith M, Fayad L, Romaguera J, Hagemeister F et al (2008) Phase II multicenter study of oblimersen sodium, a $\mathrm{Bcl}-2$ antisense oligonucleotide, in combination with rituximab in patients with recurrent B-cell non-Hodgkin lymphoma. Br J Haematol 143:355-360

Prudent J, Popgeorgiev N, Bonneau B, Thibaut J, Gadet R, Lopez J et al (2013) Bcl-wav and the mitochondrial calcium uniporter drive gastrula morphogenesis in zebrafish. Nat Commun 4:2330

Qiu Y, Yu T, Wang W, Pan K, Shi D, Sun H (2014) Curcumin-induced melanoma cell death is associated with mitochondrial permeability transition pore (mPTP) opening. Biochem Biophys Res Commun 448:15-21

Quast SA, Berger A, Buttstädt N, Friebel K, Schönherr R, Eberle J (2012) General sensitization of melanoma cells for TRAILinduced apoptosis by the potassium channel inhibitor TRAM34 depends on release of SMAC. PLoS One 7:e39290

Ralph SJ, Rodríguez-Enríquez S, Neuzil J, Saavedra E, MorenoSánchez R (2010) The causes of cancer revisited: "mitochondrial malignancy" and ROS-induced oncogenic transformation-why mitochondria are targets for cancer therapy. Mol Aspects Med 31:145-170

Rasola A, Bernardi P (2011) Mitochondrial permeability transition in $\mathrm{Ca}(2+)$-dependent apoptosis and necrosis. Cell Calcium $50: 222-233$

Rasola A, Bernardi P (2014) The mitochondrial permeability transition pore and its adaptive responses in tumor cells. Calcium 56:437-445

Raviv Z, Cohen S, Reischer-Pelech D (2013) The anti-cancer activities of jasmonates. Cancer Chemother Pharmacol 71:275-285

Reddy PH (2013) Is the mitochondrial outer membrane protein VDAC1 therapeutic target for Alzheimer's disease? Biochim Biophys Acta 1832:67-75

Reina S, Checchetto V, Saletti R, Gupta A, Chaturvedi D, Guardiani C et al (2016) VDAC3 as a sensor of oxidative state of the intermembrane space of mitochondria: the putative role of cysteine residue modifications. Oncotarget 7:2249-2268

Richardson AL, Wang ZC, De Nicolo A, Lu X, Brown M, Miron A et al (2006) X chromosomal abnormalities in basal-like human breast cancer. Cancer Cell 9:121-132

Riker AI, Enkemann SA, Fodstad O, Liu S, Ren S, Morris C et al (2008) The gene expression profiles of primary and metastatic melanoma yields a transition point of tumor progression and metastasis. BMC Med Genomics 1:13 
Rizzuto R, De Stefani D, Raffaello A, Mammucari C (2012) Mitochondria as sensors and regulators of calcium signalling. Nat Rev Mol Cell Biol 13:566-578

Roderick HL, Cook SJ (2008) $\mathrm{Ca}^{2+}$ signalling checkpoints in cancer: remodelling $\mathrm{Ca}^{2+}$ for cancer cell proliferation and survival. Nat Rev Cancer 8:361-375

Rom J, von Minckwitz G, Marmé F, Ataseven B, Kozian D, Sievert M, Schlehe B, Schuetz F et al (2009) Phase I study of apoptosis gene modulation with oblimersen within preoperative chemotherapy in patients with primary breast cancer. Ann Oncol 20:1829-1835

Rosenwald A, Alizadeh AA, Widhopf G, Simon R, Davis RE, Yu X et al (2001) Relation of gene expression phenotype to immunoglobulin mutation genotype in B cell chronic lymphocytic leukemia. J Exp Med 194:1639-1647

Roy SS, Madesh M, Davies E, Antonsson B, Danial N, Hajnoczky G (2009) Bad targets the permeability transition pore independent of Bax or Bak to switch between $\mathrm{Ca}^{2+}$-dependent cell survival and death. Mol Cell 33:377-388

Ruszna`k Z, Bakondi G, Kosztka L, Pocsai K, Dienes B, Fodor J et al (2008) Mitochondrial expression of the two-pore domain TASK-3 channels in malignantly transformed and non-malignant human cells. Virchows Arch 452:415-426

Sah P (1996) $\mathrm{Ca}^{2+}$-activated $\mathrm{K}^{+}$currents in neurones: types, physiological roles and modulation. Trends Neurosci 19:150-154

Sakamoto K, Ohya S, Muraki K, Imaizumi Y (2008) A novel opener of large-conductance $\mathrm{Ca}^{2+}$-activated $\mathrm{K}^{+}(\mathrm{BK})$ channel reduces ischemic injury in rat cardiac myocytes by activating mitochondrial K(Ca) channel. J Pharmacol Sci 108:135-139

Samudio I, Fiegl M, McQueen T, Clise-Dwyer K, Andreeff M (2008) The Warburg effect in leukemia-stroma cocultures is mediated by mitochondrial uncoupling associated with uncoupling protein 2 activation. Cancer Res 68:5198-5205

Sassi N, De Marchi U, Fioretti B, Biasutto L, Gulbins E, Francolini F, Szabò I, Zoratti M (2010) An investigation of the occurrence and properties of the mitochondrial intermediate conductance $\mathrm{Ca}^{2+}$-activated $\mathrm{K}^{+}$channel $\mathrm{mtKCa} 3.1$. Biochim Biophys Acta Bioenergetics 1797:260-1267

Sciacovelli M, Guzzo G, Morello V, Frezza C, Zheng L, Nannini N et al (2013) The mitochondrial chaperone TRAP1 promotes neoplastic growth byinhibiting succinate dehydrogenase. Cell Metab 17:988-999

Seo MD, Enomotoc M, Ishiyama N, Stathopulos PB, Ikura M (2015) Structural insights into endoplasmic reticulum stored calcium regulation by inositol 1,4,5-trisphosphate and ryanodine receptor. Biochim Biophys Acta 1853:1980-1991

Shanmughapriya S, Rajan S, Hoffman NE, Higgins AM, Tomar D, Nemani N, et al. (2015) SPG7 is an essential and conserved component of the mitochondrial permeability transition pore. Mol Cell 60:47-62

Shapovalov G, Ritaine A, Skryma R, Prevarskaya N (2016) Role of TRP ion channels in cancer and tumorigenesis. Semin Immunopathol 38:357-369

Shi Y, Chen J, Weng C, Chen R, Zheng Y, Chen Q et al (2003) Identification of the protein-protein contact site and interaction mode of human VDAC1 with Bcl-2 family proteins. Biochem Biophys Res Comm 305:989-996

Shibao K, Fiedler MJ, Nagata J, Minagawa N, Hirata K, Nakayama Y et al (2010) The type III inositol 1,4,5-trisphosphate receptor is associated with aggressiveness of colorectal carcinoma. Cell Calcium 48:315-323

Shimizu S, Ide T, Yanagida T, Tsujimoto Y (2000) Electrophysiological study of a novel large pore formed by Bax and the voltagedependent anion channel that is permeable to cytochrome $\mathrm{c}$. $\mathbf{J}$ Biol Chem 275:12321-12325
Shimojo M, Shudo Y, Ikeda M, Kobashi T, Ito S (2013) The small cell lung cancer-specific isoform of RE1-silencing transcription factor (REST) is regulated by neural-specific Ser/Arg repeat-related protein of $100 \mathrm{kDa}(\mathrm{nSR} 100)$. Mol Cancer Res 11:1258-1268

Shoshan-Barmatz V, Golan M (2012) Mitochondrial VDAC1: function in cell life and death and a target for cancer therapy. Curr Med Chem 19:714-735

Shoshan-Barmatz V, Mizrachi D (2012) VDAC1: from structure to cancer therapy. Front Oncol 2:164

Shoshan-Barmatz V, Hadad N, Feng W, Shafir I, Orr I, Varsanyi M, Heilmeyer LM (1996) VDAC/porin is present in sarcoplasmic reticulum from skeletal muscle. FEBS Lett 386:205-210

Shoshan-Barmatz V, Zalk R, Gincel D, Vardi N (2004) Subcellular localization of VDAC in mitochondria and ER in the cerebellum. Biochim Biophys Acta 1657:105-114

Shoshan-Barmatz V, De Pinto V, Zweckstetter M, Raviv Z, Keinan N, Arbel N (2010) VDAC, a multi-functional mitochondrial protein regulating cell life and death. Mol Asp Med 31:227-285

Shoshan-Barmatz V, Ben-Hail D, Admoni L, Krelin Y, Tripathi SS (2015) The mitochondrial voltage-dependent anion channel 1 in tumor cells. Biochimica et Biophysica Acta 1848(10 Pt B):2547-2575

Simamura E, Shimada H, Hatta T, Hirai K (2008) Mitochondrial voltage-dependent anion channels (VDACs) as novel pharmacological targets for anti-cancer agents. J Bioenerg Biomembr 40:213-217

Singh H, Stefani E, Toro L (2012) Intracellular BKCa (iBKCa) channels. J Physiol 590:5937-5947

Skalska J, Piwónska M, Wyroba E, Surmacz L, Wieczorek R, Koszela-Piotrowska I, Zielínska J, Bednarczyk P, Dołowy K, Wilczynski GM, Szewczyk A, Kunz WS (2008) A novel potassium channel in skeletal muscle mitochondria. Biochim Biophys Acta 1777:651-659

Skalska J, Bednarczyk P, Piwonska M, Kulawiak B, Wilczynski G, Dolowy K, Kudin AP, Kunz WS, Szewczyk A (2009) Calcium ions regulate $\mathrm{K}^{+}$uptake into brain mitochondria: the evidence for a novel potassium channel. Int J Mol Sci 10:1104-1120

Skotheim RI, Lind GE, Monni O, Nesland JM, Abeler VM, Fosså SD et al (2005) Differentiation of human embryonal carcinomas in vitro and in vivo reveals expression profiles relevant to normal development. Cancer Res 65:5588-5598

Sokolowski B, Orchard S, Harvey M, Sridhar S, Sakai Y (2011) Conserved BK channel protein interactions reveal signals relevant to cell death and survival. PLoS ONE 6:e28532

Steinle M et al (2011) Ionizing radiation induces migration of glioblastoma cells by activating $\mathrm{BK} \mathrm{K}^{+}$channels. Radiother Oncol 101:122-126

Storz MN, van de Rijn M, Kim YH, Mraz-Gernhard S, Hoppe RT, Kohler S (2003) Gene expression profiles of cutaneous B cell lymphoma. J Invest Dermatol 120:865-870

Suh KS, Malik M, Shukla A, Ryscavage A, Wright L, Jividen K et al (2012) CLIC4 is a tumor suppressor for cutaneous squamous cell cancer. Carcinogenesis 33:986-995

Suh DH, Kim MK, Kim HS, Chung HH, Song YS (2013) Mitochondrial permeability transition pore as a selective target for anticancer therapy. Front Oncol 3:41

Sung PJ, Tsai FD, Vais H, Court H, Yang J, Fehrenbacher N et al (2013) Phosphorylated K-Ras limits cell survival by blocking Bcl-xL sensitization of inositol trisphosphate receptors. Proc Natl Acad Sci USA 110:20593-20598

Szabo I, Zoratti M (1991) The giant channel of the inner mitochondrial membrane is inhibited by cyclosporin A. J Biol Chem 266(1991):3376-3379

Szabo I, Zoratti M (1992) The mitochondrial megachannel is the permeability transition pore. J Bioenerg Biomembr 24:111-117 
Szabò I, Zoratti M (2014) Mitochondrial channels: ion fluxes and more. Phys Rev 94:519-608

Szabo I, Trentin L, Trimarco V, Semenzato G, Leanza L (2015) Biophysical characterization and expression analysis of Kv1.3 potassium channel in primary human leukemic B cells. Cell Physiol Biochem 37:965-978

Szabó I, Bock J, Grassmé H, Soddemann M, Wilker B, Lang F, Zoratti M, Gulbins E (2008) Mitochondrial potassium channel Kv1.3 mediates Bax-induced apoptosis in lymphocytes. Proc Natl Acad Sci U S A 105:14861-14866

Szabò I, Bock J, Jekle A, Soddemann M, Adams C, Lang F, Zoratti M, Gulbins E (2005) A novel potassium channel in lymphocyte mitochondria. J Biol Chem 280:12790-12798

Szabò I, Soddemann M, Leanza L, Zoratti M, Gulbins E (2011) Single-point mutations of a lysine residue change function of Bax and Bcl-xL expressed in Bax-and Bak-less mouse embryonic fibroblasts: novel insights into the molecular mechanisms of Bax-induced apoptosis. Cell Death Differ 18:427-438

Szabò I, Leanza L, Gulbins E, Zoratti M (2012) Physiology of potassium channels in the inner membrane of mitochondria. Pflugers Arch 463:231-246

Szatkowski C, Parys JB, Ouadid-Ahidouch H, Matifat F (2010) IRneseoarschitol 1,4,5-trisphosphate-induced $\mathrm{Ca}^{2+}$ signalling is involved in estradiol-induced breast cancer epithelial cell growth. Mol Cancer 9:156

Szewczyk A, Kajma A, Malinska D, Wrzosek A, Bednarczyk P, Zabłocka B, Dołowy K (2010) Pharmacology of mitochondrial potassium channels: dark side of the field. FEBS Lett 584:2063-2069

Tajeddine N, Galluzzi L, Kepp O, Hangen E, Morselli E, Senovilla L et al (2008) Hierarchical involvement of Bak, VDAC1 and Bax in cisplatin-induced cell death. Oncogene 27:4221-4232

Tang HY, Beer LA, Tanyi JL, Zhang R, Liu Q, Speicher DW (2013) Protein isoform specific validation defines multiple chloride intracellular channel and tropomyosin isoforms as serological biomarkers of ovarian cancer. J Proteome 89:165-178

Tang S, Wang X, Shen Q, Yang X, Yu C, Cai C et al (2015) Mitochondrial $\mathrm{Ca}^{2+}$ uniporter is critical for store-operated $\mathrm{Ca}^{2+}$ entrydependent breast cancer cell migration. Biochem Biophys Res Commun 458:186-193

Tosatto A, Sommaggio R, Kummerow C, Bentham RB, Blacker TS, Berecz $\mathrm{T}$ et al (2016) The mitochondrial calcium uniporter regulates breast cancer progression via HIF-1alpha. EMBO Mol Med 8:569-585

Tovar-Mendez A, Miernyk JA, Randall DD (2003) Regulation of pyruvate dehydrogenase complex activity in plant cells. Eur $\mathbf{J}$ Biochem 270:1043-1049

Trachootham D, Alexandre J, Huang P (2009) Targeting cancer cells by ROS-mediated mechanisms: a radical therapeutic approach? Nat Rev Drug Discov 8:579-591

Tsunoda T, Koga H, Yokomizo A, Tatsugami K, Eto M, Inokuchi J et al (2005) Inositol 1,4,5-trisphosphate (IP3) receptor type1 (IP3R1) modulates the acquisition of cisplatin resistance in bladder cancer cell lines. Oncogene 24:1396-1402

Urrego D et al (2014) Potassium channels in cell cycle and cell proliferation. Philos Trans R Soc Lond B Biol Sci 369:20130094

Valero MLI, Mello de Queiroz F, Stuhmer W, Viana F, Pardo LA (2012) TRPM8 ion channels differentially modulate proliferation and cell cycle distribution of normal and cancer prostate cells. PLoS One 7:e51825

Vicente R, Escalada A et al (2006) Association of Kv1.5 and Kv1.3 contributes to the major voltage-dependent $\mathrm{K}^{+}$channel inmacrophages. J Biol Chem 281:37675-37685

Vozza A, Parisi G, De Leonardis F, Lasorsa FM, Castegna A, Amorese D, Marmo R, Calcagnile VM, Palmieri L, Ricquier D, Paradies E, Scarcia P, Palmieri F, Bouillaud F, Fiermonte G (2014)
UCP2 transports C4 metabolites out of mitochondria, regulating glucose and glutamine oxidation. Proc Natl Acad Sci U S A 111:960-965

Wagner S, De Bortoli S, Schwarzländer M, Szabò I (2016) Regulation of mitochondrial calcium in plants versus animals. J Exp Bot pii:erw 100

Wang Z (2004) Roles of $\mathrm{K}^{+}$channels in regulating tumour cell proliferation and apoptosis. Pflugers Arch 448:274-286

Wang X, Zhang X, Dong XP, Samie M, Li X, Cheng X et al (2012) TPC proteins are phosphoinositide-activated sodium-selective ion channels in endosomes and lysosomes. Cell 151:372-383

Wang Y, Yang Z, Meng Z, Cao H, Zhu G, Liu T, Wang X (2014) Knockdown of TRPM8 suppresses cancer malignancy and enhances epirubicin-induced apoptosis in human osteosarcoma cells. Int J Biol Sci 10:90-102

Welsh JB, Zarrinkar PP, Sapinoso LM, Kern SG, Behling CA, Monk BJ et al (2001) Analysis of gene expression profiles in normal and neoplastic ovarian tissue samples identifies candidate molecular markers of epithelial ovarian cancer. Proc Natl Acad Sci USA 98:1176-1181

Wolf FI, Trapani V (2009) Multi drug resistance phenotypes and MRS2 mitochondrial magnesium channel: two players from one stemness. Cancer Biol Ther 8:615-617

Wu Y, Rasmussen TP, Koval OM, Joiner ML, Hall DD, Chen B et al (2015) The mitochondrial uniporter controls fight or flight heart rate increases. Nat Commun 6:6081

Wulff H, Castle NA (2010) Therapeutic potential of KCa3.1 blockers: recent advances and promising trends. Expert Rev Clin Pharmacol 3:385-396

Xu X, Decker W, Sampson MJ, Craigen WJ, Colombini M (1999) Mouse VDAC isoforms expressed in yeast: channel properties and their roles in mitochondrial outer membrane permeability. J Membr Biol 170:89-102

Xu W, Liu Y, Wang S, McDonald T, Van Eyk JE, Sidor A et al (2002) Cytoprotective role of $\mathrm{Ca}^{2+}$ - activated $\mathrm{K}^{+}$channels in the cardiac inner mitochondrial membrane. Science 298:1029-1033

Xu Y, Kang J, Yuan Z, Li H, Su J, Li Y, Kong X, Zhang H, Wang W, Sun L (2013) Suppression of CLIC4/mtCLIC enhances hydrogen peroxide-induced apoptosis in C6 glioma cells. Oncol Rep 29:1483-1491

Xu H, Martinoia E, Szabo I (2015) Organellar channels and transporters. Cell Calcium 58:1-10

Yagoda N, von Rechenberg M et al (2007) RAS-RAF-MEK-dependent oxidative cell death involving voltage-dependent anion channels. Nature 447:864-868

Yang Z, Schumaker LM, Egorin MJ, Zuhowski EG, Guo Z, Cullen KJ (2006) Cisplatin preferentially binds mitochondrial DNA and voltage-dependent anion channel protein in the mitochondrial membrane of head and neck squamous cell carcinoma: possible role in apoptosis. Clin Cancer Res 12:5817-5825

Yee NS (2015) Roles of TRPM8 Ion Channels in Cancer: proliferation, Survival, and Invasion. Cancers (Basel) 7:2134-2146

Yoo HJ et al (2009) Genetic and expression alterations in association with the sarcomatous change of cholangiocarcinoma cells. Exp Mol Med 41:102-115

Yoshihara K, Tajima A, Komata D, Yamamoto T, Kodama S, Fujiwara $\mathrm{H}$ et al (2009) Gene expression profiling of advancedstage serous ovarian cancers distinguishes novel subclasses and implicates ZEB2 in tumor progression and prognosis. Cancer Sci 100:1421-1428

Yu G, Liu J, Xu K, Dong J (2015a) Uncoupling protein 2 mediates resistance to gemcitabine-induced apoptosis in hepatocellular carcinoma cell lines. Biosci Rep 35:e00231

Yu X, Luo A, Liu Y, Wang S, Li Y, Shi W, Liu Z, Qu X (2015b) MiR214 increases the sensitivity of breast cancer cells to tamoxifen 
and fulvestrant through inhibition of autophagy. Mol Cancer 14:208

Yuan S, Fu Y, Wang X, Shi H, Huang Y, Song X, Li L, Song N, Luo Y (2008) Voltage dependent anion channel 1 is involved in endostatin-induced endothelial cell apoptosis. FASEB J 22:2809-2820

Yusenko MV, Kuiper RP, Boethe T, Ljungberg B, van Kessel AG, Kovacs G (2009) High-resolution DNA copy number and gene expression analyses distinguish chromophobe renal cell carcinomas and renal oncocytomas. BMC Cancer 9:152

Zaid H, Abu-Hamad S, Israelson A, Nathan I, Shoshan-Barmatz V (2005) The voltage dependent anion channel-1 modulates apoptotic cell death. Cell Death Differ 12:751-760

Zhang L, Barritt GJ (2004) Evidence that TRPM8 is an androgen dependent $\mathrm{Ca}^{2+}$ channel required for the survival of prostate cancer cells. Cancer Res 64:8365-8373

Zhang K, Shang Y, Liao S, Zhang W, Nian H (2007) Uncoupling protein 2 protects testicular germ cells from hyperthermia-induced apoptosis. Biochem Biophys Res Commun 360:327-332
Zhang LY, Wu YL, Gao XH, Guo F (2014) Mitochondrial protein cyclophilin-D-mediated programmed necrosis attributes to berberine-induced cytotoxicity in cultured prostate cancer cells. Biochem Biophys Res Commun 450:697-703

Zhong J, Kong X, Zhang H, Yu C, Xu Y, Kang J et al (2012) Inhibition of CLIC4 enhances autophagy and triggers mitochondrial and ER stress-induced apoptosis in human glioma U251 cells under starvation. PLoS One 7:e39378

Zhu J, Yan J, Thornhill WB (2014) The Kv1.3 potassium channel is localized to the cis-Golgi and Kv1.6 is localized to the endoplasmic reticulum in rat astrocytes. FEBS J 281:3433-3445

Zoratti M, Szabo I (1995) The mitochondrial permeability transition. Biochim Biophys Acta 1241(2):139-176 